Volume (3) No. (3) 2020

فعالية استراتيجية الخرائط الذهنية في تنمية المفاهيم التاريخية والتفكير البصري وبعض عادات العقل لدى تلاميذ الصف الرابع الابتدائي

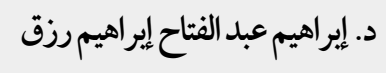


فعالية استراتيجية الخر ائط الذهنية في تنمية المفاهيم التاريخية والتفكير البصري وبعض عادات العقل لدى تلاميذ الصف الر ابع الابتدائي

$$
\text { د. إبر اهيم عبد الفتاح إبر اهيم رزق }
$$

أستاذ مساعد المناهج وطرق تدريس الدراسات الاجتحاعية، كلية التربية، جامعة العريش، مصر rezq70@hotmail.com

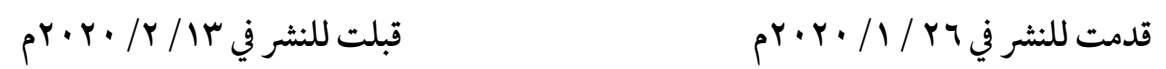

الملخص: تحددت مشكلة البحث في "وجود ضعف لدىن تلاميذ الصف الرابع الابتدائي في تعلم المفاهيم التاريخية ومهارات التفكير البصري وممارسة عادات العقل بسبب اعتماد تدريس التاريخ في المرحلة الابتدائية علن الأساليب التقليدية القائمة علن التلقين من قبل المعلم والحفظ والاستظهار من جانب المتعلمين، والاهتحام بوظائف النصف الأيسر للمخ والمتمثلة في العمليات المنطقية والتحليلية اللفظية والعددية، بينها تهمل العمليات الابتكارية والوجدانية والمكانية البصرية والتي هي من وظائف النصف الأيمن للمخ، مما أدىن إلى سيطرة النصف الكروي الأيسر في التعامل مع المعرفة والمعلومات التاريخية" ومن ثم استهدفت البحث إعداد وحدتين من منهج التاريخ للصف الرابع الابتدائي وفق استراتيجية الخرائط الذهنية؛ لقياس فعالية استراتيجية الخرائط الذهنية في تنمية المفاهيم التاريخية و التفكير البصري وبعض عادات العقل لدى تلاميذ الصف الرابع الابتدائي، وقد اتبع البحث المنهج الوصفي التحليلي في إعداد الإطار النظري، والمنهج شبه التجريبي عند بناء الوحدتين وفق استراتيجية الخرائط الذهنية، وإعداد أدوات البحث والتجريب الميداني، وفي ضوء تفسير النتائج تم التوصل إلى توصيات ومقترحات من أهمها عقد دورات تدريبية لمعلمي وموجهي التاريخ بالمرحلة لتدريبهم علن كيفية استخدام الخرائط الذهنية في تدريس التاريخ، وتوجيه نظر القائمين علن تطوير المناهج بإعادة النظر في تحطيط وتنظيم محتوى كتب التاريخ في المرحلة الابتدائية لتضمين كتب التاريخ بعض نهاذج للخر ائط الذهنية وأنشطة بصرية ومهام تعليمية بما يتلاءم مع المحتوئ الدراسي، وأيضاً إعداد أدلة لمعلم الدراسات الاجتماعية بالمرحلة الابتدائية؛ لمساعدة المعلم على تدريس التاريخ باستخدام الخرائط الذهنية. 
Volume (3) No. (3) 2020

الكلمات الدلالية: الخرائط الذهنية، المفاهيم التاريخية، التفكير البصري، عادات العقل، تدريس التاريخ، المرحلة الابتدائية 


\section{The effectiveness of mental mapping strategy in developing historical concepts, visual thinking and some habits of mind among fourth grade primary school students}

Dr. Ibrahim Abdulfattah Rezq

Assistant Professor of Curricula and Instructions of Social Studies, Coolege of Education, Al-Areesh University, Egypt rezq70@hotmail.com

Received in 26th January 2020

Accepted in 13th February 2020

Abstract: The problem of research was determined in the "weakness of fourth grade students in learning historical concepts and skills of visual thinking and practice habits of mind because of the dependence of teaching history at the primary level on traditional methods based on the teacher's memorization and memorization by learners, and attention to the functions of the left half The brain, represented by logical and analytical and numerical processes, while neglecting the innovative, emotional and spatial processes, which are functions of the right hemisphere of the brain, resulting in the control of the left hemisphere in dealing with knowledge and Therefore, the research aimed to prepare two units of history curriculum for the fourth grade of primary according to the strategy of mental maps; The semi-experimental approach when building the two units according to the strategy of mental maps, and the preparation of research tools and field experimentation, and in the light of the interpretation of the results were reached recommendations and proposals, the most important of which are the following: Holding training courses for history teachers and mentors at the stage to train them on how to use mind maps in teaching history. To draw the attention of those who develop curricula by reviewing the planning and organization of the content of history books in the primary stage to include history books some models of mental maps and visual activities and educational tasks in accordance with the content of the study. And Preparation of guides for the teacher of social studies at the primary level; to help the teacher to teach history using mental maps. 
Volume (3) No. (3) 2020

Key Words: Mental Maps, Historical Concepts, Visual Thinking, Habits Of Mind, Teaching History, Elementary School. 
أصبحت ساحة الدراسات التاريخية تموج بالعديد من القراءات التاريخية والرؤئ المختلفة نتيجة التطور السريع والانفجار المعرفي، وقد بلغ ذلك حدا يمكن معه القول بأن تلقين النشء بعض المعارف التاريخية لا يعدهم للمستقبل، ولا يزودهم بالأدوات التي تمكنهم من نقد وتحليل تلك الرؤين المختلفة للتاريخ، ويترك المتعلمين فريسة لتيارات فكرية مغرضة تستهدف تشويه الذاكرة التاريخية والحيلولة دون وعي الدرس التاريخي وتفعيله في صناعة الحاضر واستشر اف المستقبل. وهذا يفرض علن المؤسسة التعليمية ـ وربيا أكثر من أي وقت مضئ ـ ضرورة تنمية العادات العقلية التي تمكن المتعلم من أن يكون مستقصيا ناجحا في دراسته للتاريخ بحيث يكون موضو عيا في حكمه، مقدر القيمة الأدلة والشواهد في فحص دقة المعلومات، راغبا في الابتعاد عن التسرع في اصدار الأحكام التاريخية، وأن يكون قادرا علن تحمل غموض بعض الأحداث التاريخية، وقبل هذا كله أن يكون محبا للاطلاع، وأن يستخدم العقل في حل المشكلات (شلبي وآخرون، 1991 1، • ع )، وكلها عادات عقلية تلعب دورا مها في الاستقصاء التاريخي سواء بجعله ممكنا أو للاستمرار فيه (باير، .(Or 6998

و تدعو أساليب التربية الحديثة إلى أن تكون العادات العقلية هدفا رئيسا في جميع مراحل التعليم؛ لأن العادات العقلية سلوكيات قد يصعب اداؤها بصورة تلقائية إذا لر يتدرب المتعلمون عيها، وتتو افر


ويرى كوستا أنه لا فائدة من أن يتعلم الطالب محتوكن ما إذا لم يتعلم السعي لتحقيق الدقة والوضوح، وتجنب الاندفاع، والمثابرة العقلية ؛ من أجل استخدام المعرفة وتطبيقها، وليس حفظها واستذكارها

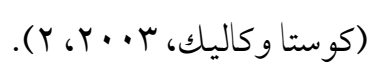

ويؤكد باير (Beyer, 2003) أن العادات العقلية يجب أن يمارسها المتعلم مرارا أوتكرارا حتى لئ تصبح جزءا من طبيعته، وكذلك أشارت دراسة كوستا وكاليك ( Costa \& Kallick, 2000$)$

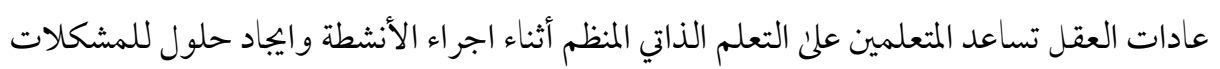


التي تو اجهرم، وتؤكد روتا (Rotta, 2004) أن تنمية العادات العقلية يساعد في تنظيم المخزون المعرفي


وتشير الدراسات إلى أن العادات العقلية الضعيفة تؤدي إلى تعلم ضعيف (Marzano, 2000) كما أن اهمال استخدام عادات العقل يسبب الكثير من القصور في نتائج العملية التعليمية ( Costa, .(2001

لذلك أكدت العديد من الدراسات منذ بداية القرن الحادي والعشرين أهمية تعليم العادات العقلية وتقويتها ومناقشتها مع المتعلمين، والتفكير فيها وتقويمها، وتقديم التعزيز اللازم للمتعلمين من أجل تشجيعهم علن التمسك بها، حتى تصبح جزءامن ذاتهم وبنيتهم العقلية (قطامي، V. . Y)، كما أجريت بعض الدراسات التي أستخدمت طرق واستراتيجيات ونماذج مختلفة لتنميتها منها:

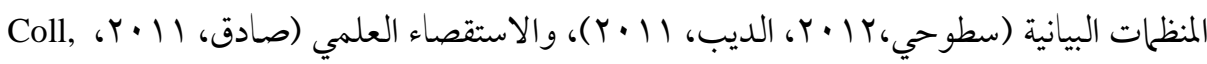

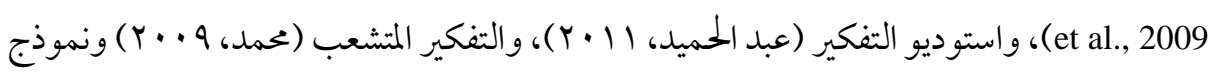

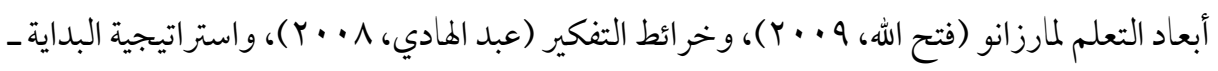

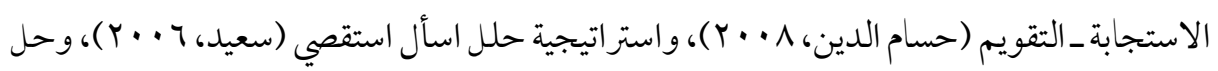
المشكلات (Coombs, 2001, Angelique, 2000).

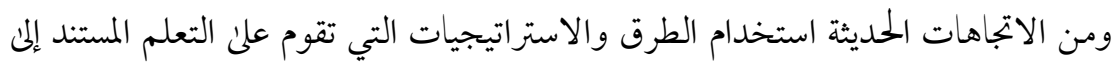

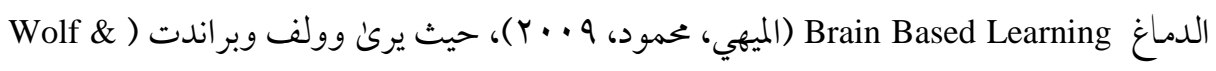
(Brandt, 1999 إلى زيادة الاهتحام بتنمية العادات العقلية لدى' تلاميذ جميع المراحل. فقد تميزت بحوث العقل البشري بالثراء الذي قاد إلى ظهور نظرية التعلم المستند إلى الدماغ، لتكون الجسر الذي يصل نتائج الأبحاث الدماغية بعملية التعلم، وقد أظهرت هذه النظرية دورا حيويا للدماغ في تعلم الانسان وطريقة اكتسابه المعرفة والخبرات، وها أهمية كبيرة في غختلف المجالات و النو احي التعليمية (زيتون، ا · ب) ؛ فالتعلم وفقا هذه النظرية هو عمل يقوم به الجسم البشري ككل 
حيث إن الدماغ والجسلد يقومان بمعالجة المعطيات بشكل متزامن، وليس بشكل متعاقب، ويقومان



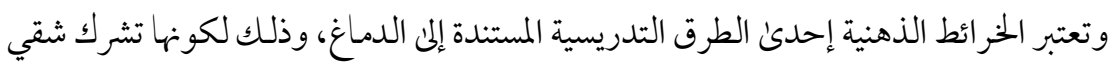

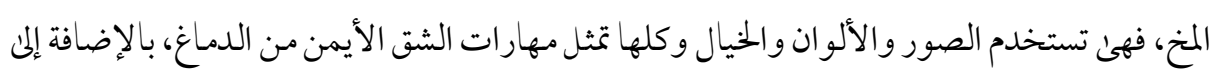

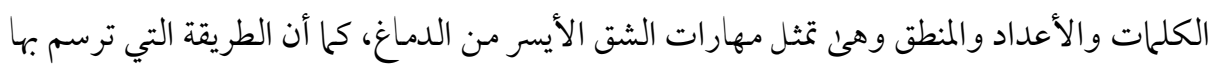

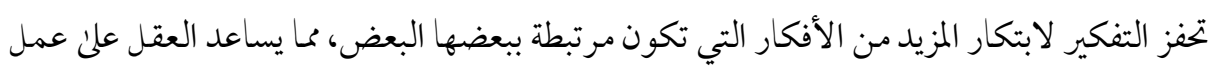

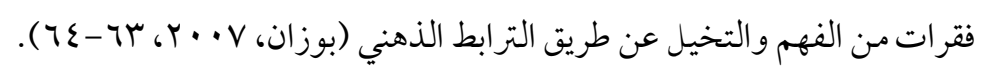

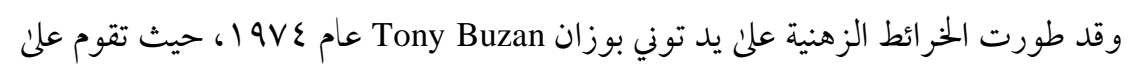

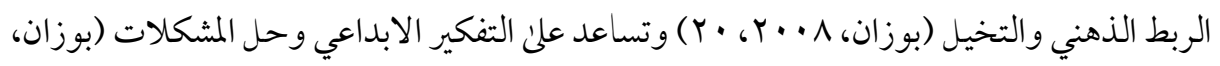

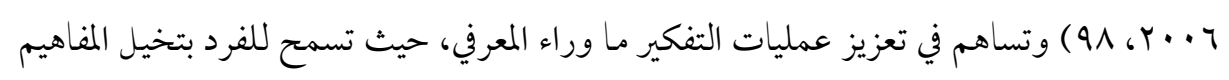

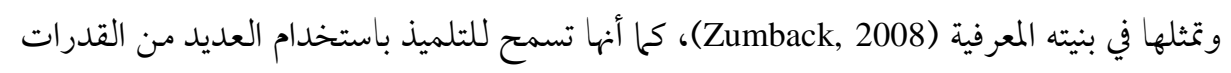

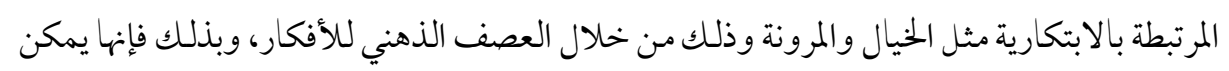
أن تساهم في تنمية عادات العقل. وهناك بعض الدراسات التي أوضحت فعالية الحرائط المعرفية في تنمية التفكير ما وراء المعرفي Leonidas, والتفكير الابداعي (طلبة 9.9 T. Ismail. Et al., 2010, Chaill \& Fonteyn, 1998) .(et al., 2007

كما تعد الحرائط الذهنية بمثابة أداة بصرية توضح الأفكار وتنظمها وذلك عن طريق عمل



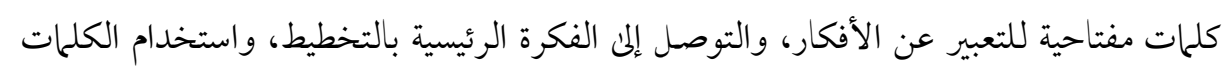

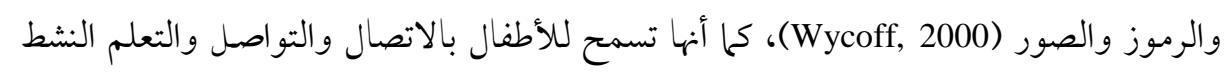
الفعال وتثثيل أفكارهم بشكل بصري. 
فعملية الإبصار تتضمن اعحال الفكر والذاكرة اللازمين للتسجيل والترتيب و المقارنة، بالإضافة إلى عمل حاسة البصر؛ حيث إن عملية التدريب مهمة لحاسة البصر، وذلك لتنمية القدرة علن الرؤية وتمييز الأشكال، ومن هنا يبرز أهمية التثقيف البصري في الدور الأساسي لعملية التعلم ذاتها (عطية، .$(190-19 r 61990$ وقد أشارت نتائج دراسة (Ganguly, 1995) إلى أن التمثيل البصري والتفكير البصري يحتاجان إلى توجيه وتدريب من جانب المعلم، كما أشارت نتائج دراسة (McCormack, 1993) إلى أن التلاميذ الذين يتمتعون بمهارات التفكير البصري يحققون معدلات كبيرة في اكتساب المفاهيم. ومن هنا فإن التفكير البصري يعمل على زيادة القدرة العقلية، وفهم المثيرات البصرية المحيطة بالمتعلم (Nemirovesky \& Tracy, 1997, 99)، وهناك العديد من الدراسات التي استخدمت برامج وطرق واستراتيجيات متنوعة لتنمية التفكير البصري لدىن التلاميذ منها: الرسوم المتحركة (حماد

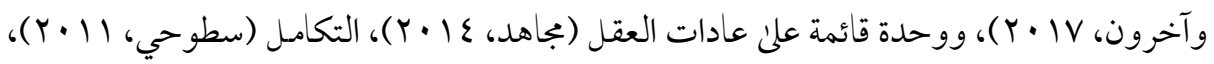

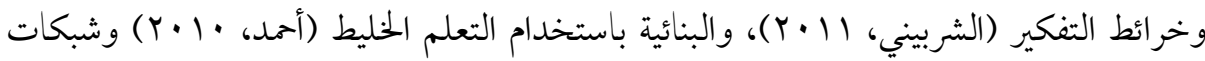

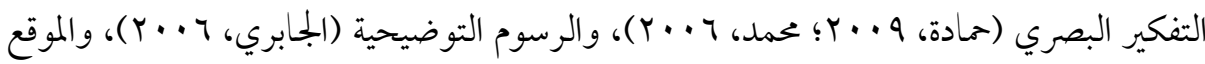



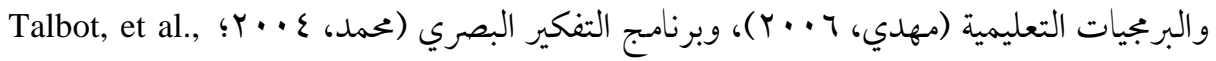
1997)، في حين اهتمت بعض الدراسات بالتعرف علن أثر الوراثة والبيئة في التفكير البصري (Zyryanova, 1998) وتعد الخر ائط الذهنية إحدى طرق تنسيق وتنظيم المعلومات والأفكار، وهئ الطريقة الأسهل

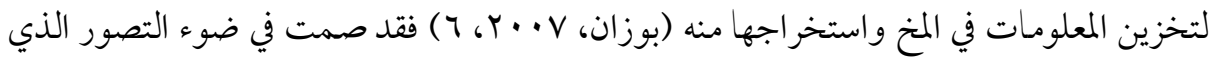
قدمته أبحاث الدماغ لكيفية عمل العقل البشري، وكيف أنه يستقبل المعلومات ويضمها إلى ما لديه من معلومات سابقة في قوائم معقدة، ويربط بينها وبين غيرها من معلومات شبيهة في خطوط معقدة ـ أيضا 
ـ تبدو وكأنها شبكات علن خلايا المخ، حيث تتمركز المفاهيم في الوصلات التي بين الخطوط وبعضها

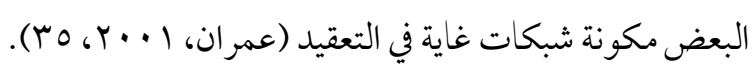

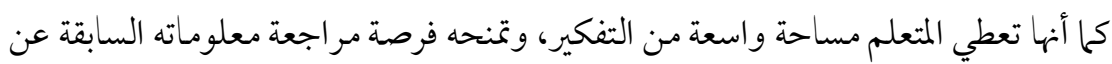

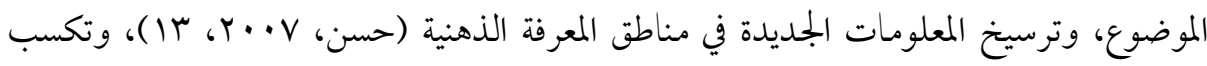

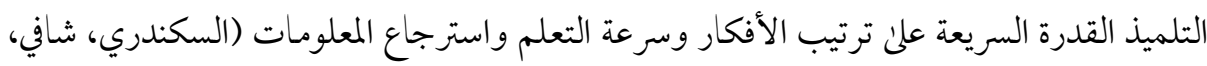

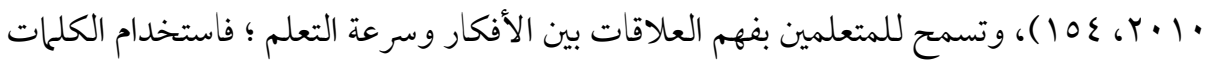

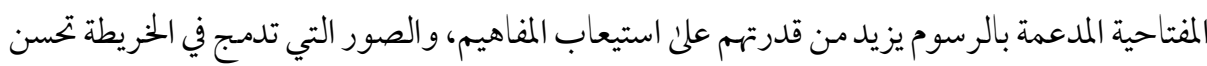

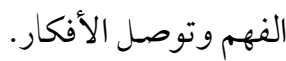

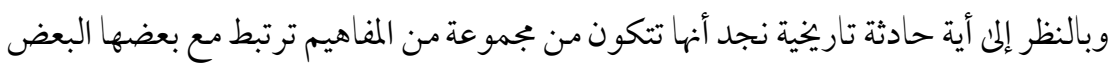


والطرق المختلفة التي تساعد في تكوين ذلك البناء وتنظيمه في عقله؛ لماله من أهمية في العملية التعليمية.

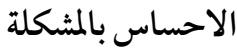

علن الرغم من أهمية تنمية عادات العقل إلا أن هناك نتائج لدراسات تشير إلن أن التلاميذ يفتقرون لتلك العادات، وعلن وجه الخصوص تلك التي ترتبط بالمواد والأنشطة الدراسية (الحارثي،

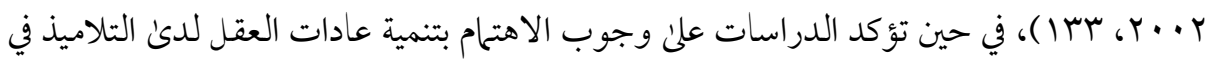

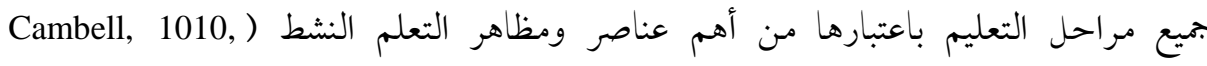


للتعليم والعمل علن تنميتها لدئ المتعلمين باستخدام طرق واستراتيجيات حديثة، وضرورة اعادة النظر في تخطيط وتنظيم كتب التاريخ وتضمينها أنشطة ومهام تعليمية لتنمية عادات العقل.



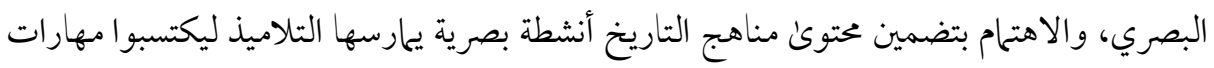
التفكير البصري. 
وبالنظر إلم واقع تدريس التاريخ في المرحلة الابتدائية من خلال الزيارات التي قام بها الباحث

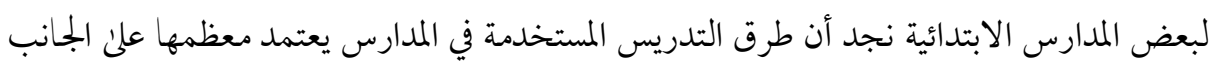



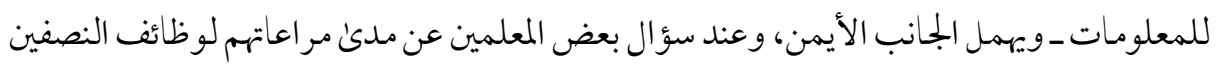

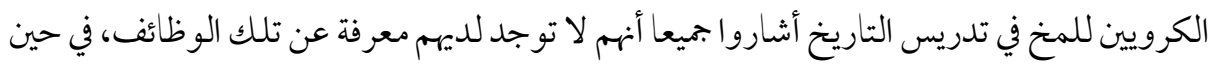

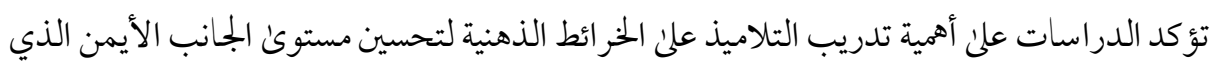



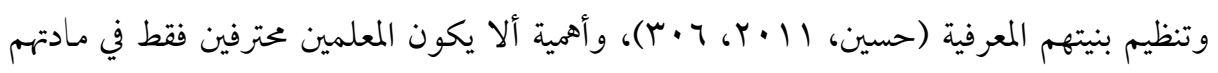

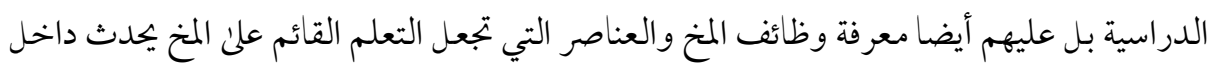

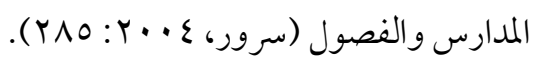
كما لاحظ الباحث أن تدريس التاريخ في المرحلة الابتدائية لا يزال يتم وفق الأساليب التقليدية التماية

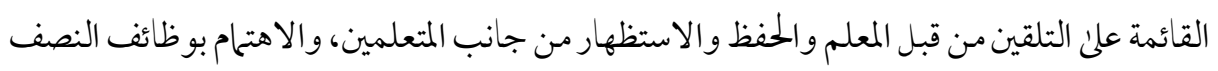

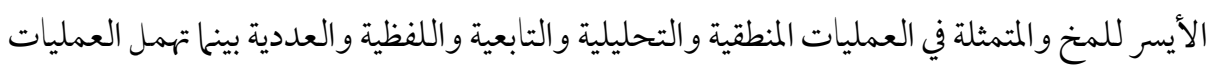



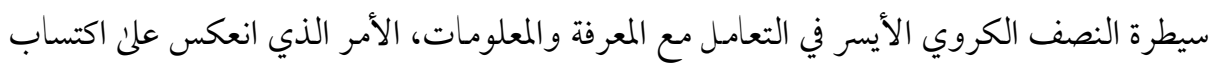

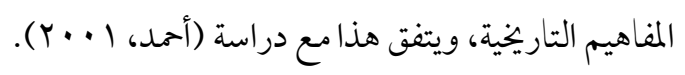

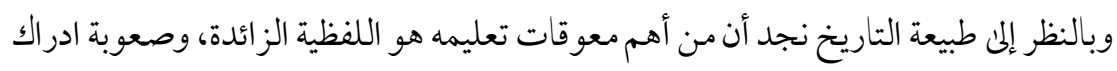

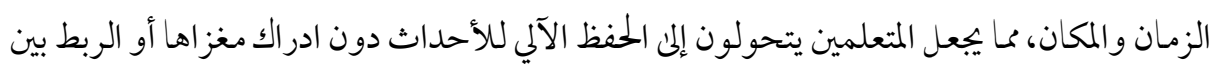

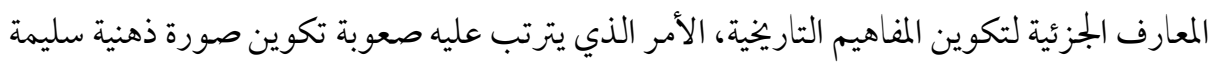

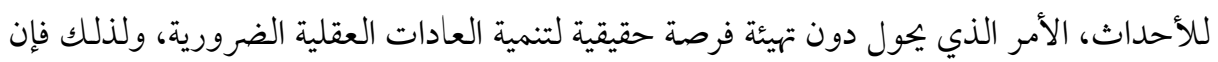

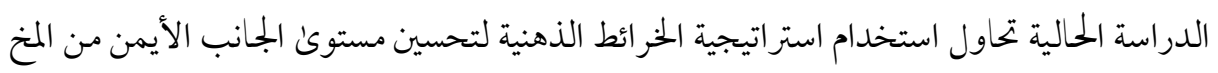

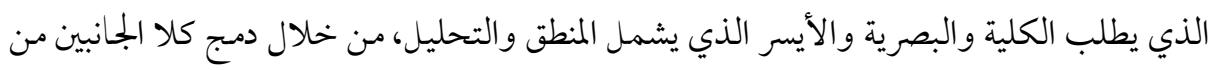


المخ للعمل معا، فهئ تساعد المعلم في تسهيل عرض وتنظيم المحتوكئ بها فيه من مفاهيم وتعميهات وتنظيم تفكير التلاميذ، كما تتيح للمعلم فرصة تنشيط المهارات العقلية المختلفة إلى الحد الذي يساعد علن تكوين المفاهيم وتنمية التفكير البصري.

مشكلة البحث

تتحدد مشكلة البحث في وجود ضعف لدى تلاميذ الصف الرابع الابتدائي في تعلم المفاهيم

التاريخية ومهارات التفكير البصري وممارسة عادات العقل، ولهذا يحاول البحث الحلالي الاجابة علن

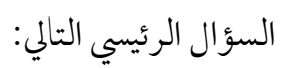

ما فعالية استخدام استراتيجية الخرائط الذهنية في تنمية المفاهيم التاريخية ومهارات التفكير

$$
\begin{aligned}
& \text { البصري وبعض عادات العقل لدئ تلاميذ الصف الرابع الابتدائي؟ } \\
& \text { ويتفرع عن السؤال الرئيسي الأسئلة التالية: }
\end{aligned}
$$

ا. ما صورة وحدتين من وحدات التاريخ في منهج الدراسات الاجتماعية للصف الرابع

$$
\text { الابتدائي وفقا لاستراتيجية الخرائط الذهنية؟ }
$$

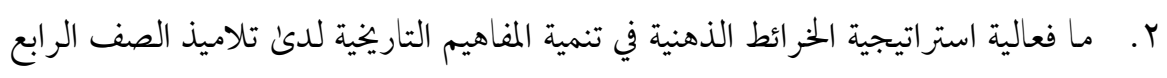

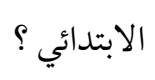

r. مـا فعالية استراتيجية الخرائط الذهنية في تنمية التفكير البصري لدئ تلاميذ الصف الرابع

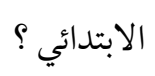

ع. ما فعالية استراتيجية الخر ائط الذهنية في تنمية بعض عادات العقل لدئ تلاميذ الصف الرابع

$$
\begin{aligned}
& \text { أهداف البحث } \\
& \text { الابتدائي }
\end{aligned}
$$

هدف البحث إلى التعرف على فعالية استراتيجية الخرائط الذهنية في تنمية المفاهيم التاريخية ومهارات التفكير البصري وبعض عادات العقل لدئ تلاميذ الصف الرابع الابتدائي. 
ا ـ مساعدة خخططي مناهج التاريخ في تخطيط موضوعات التاريخ في المرحلة الابتدائية باستخدام

$$
\text { الخر ائط الذهنية. }
$$

r. ت تقديم دليل لمعلم التاريخ لتدريس وحدتي (شخصيات وأحداث من التاريخ الفرعوني، مظاهر الحياة المصرية القديمة) وفق استراتيجية الخرائط الذهنية، ويمكن الاسترشاد به في

$$
\text { اعدادوحدات دراسية أخرىن. }
$$

r. تزويد معلمي الدراسات الاجتماعية والقائمين بالتقويم بأدوات مقننة لقياس تعلم المفاهيم

$$
\text { التاريخية، ومهارات التفكير البصري وبعض عادات العقل. }
$$

ع. اتاحة الفرصة أمـام التلاميذ عينة البحث للقيام ببناء ورسم خر ائط ذهنية بشكل تعاوني من خلال بجموعات صغيرة، مما قد يسهم في اكتساب المفاهيم التاريخية وتنمية مهارات التفكير

$$
\text { حدود البحث: اقتصر البحث على وبعض عادات العقل. }
$$

عينة من تلاميذ الصف الرابع الابتدائي بمدرسة بشتامي للتعليم الأساسي.

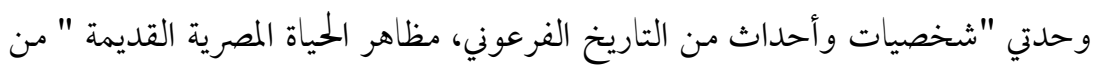
مقرر الدراسات الاجتماعية للصف الرابع الابتدائي في الفصل الدراسي الثاني من العام

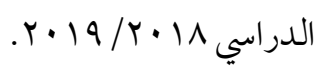

قياس المفاهيم التاريخية المنضمنة في وحدتي "شخصيات وأحداث من التاريخ الفرعوني، مظاهر الحياة المصرية القديمة" من مقرر الدراسات الاجتماعية للصف الرابع الابتدائي في

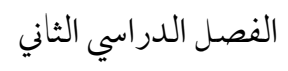

قياس مهارات التفكير البصري ( التعرف و الوصف ـ التحليل ـ ادر اك العلاقات ـ التفسير ـ

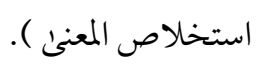


• قياس العادات العقلية (المثابرة، الاصغاء بتفهم وتعاطف، التفكير بمرونة، التساؤل وطرح

$$
\text { مصطلحات البحث } 1 \text { استراتيجية }
$$

(Brown, 1989: 79) بأنها طريقة حعددة لمعالجة مشكلة أو لمباشرة مهمة، وهي أسلوب علمي

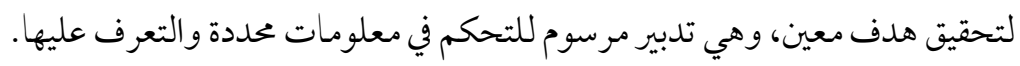

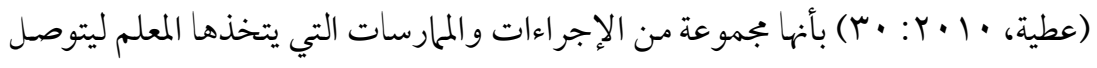



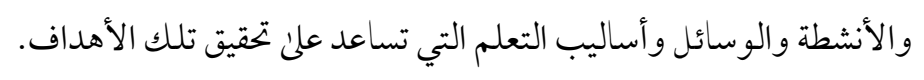



$$
\text { وخط سير الدرس. }
$$

ويعرفها الباحث إجرائيا بأنها بجموعة الإجراءات والخطوات والوسائل والأساليب التي



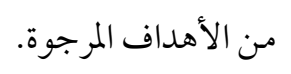

Mind Maps الخرائط الذهنية

هئ تقنية رسومية قوية تزود المتعلم بمفاتيح تساعده علن استخدام طاقة ذهنه بتسخير

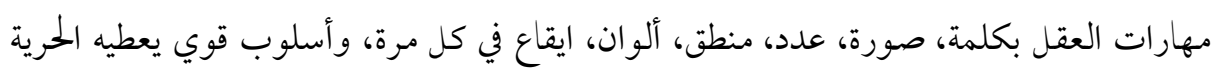

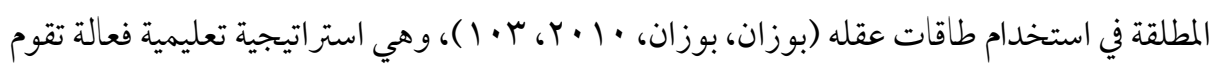

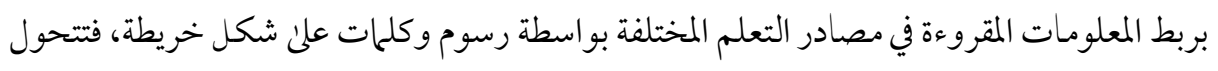

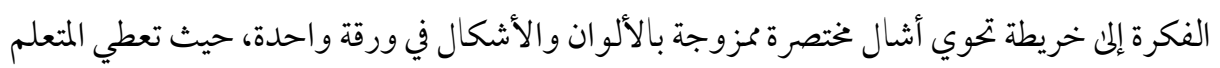


مساحة واسعة من التفكير، وتمنحة فرصة مراجعة معلوماته السابقة عن الموضوع، وترسيخ البيانات والمعلومات الجديدة في مناطق المعرفة الذهنية (حسن، V. • Y، با I). وتعرف استراتيجية الخرائط الذهنية بأنها منهج عقلي فعال وأسلوب سريع يساعد المتعلم من جانب والمعلم من جانب أخر في التنظم الجيد للبناء المعرفي والمهاري واضافة معارف جديدة لدىن كل منه|| (محمد، V... (r) ويعرفها الباحث بأنها استراتيجية تدريسية تعتمد علن جهد تعاوني من التلاميذ في التعامل مع مصادر المعرفة لاستخلاص المعلومات والأفكار واكتساب المفاهيم التاريخية وتنظيمها في بناءهم المعرفي، وترجمة ذلك في صورة خريطة ـ في ورقة واحدة بشكل مرتب ومنظم - تبرز التصور المتكامل لموضوع الدراسة، بحيث تتمركز الفكرة المركزية في المنتصف، وتتفرع منها الأفكار والمفاهيم الرئيسة و الفرعية مستخدمين الألو ان والصور والرموز،ويتم ذلك من خلال بيئة محفزة لتنمية مهارات التفكير

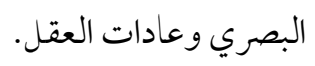

\section{عادات العقل Habits of Mind}

يعرفها "كوستاو كاليك" بأنها أنهاط الأداء العقلي الذي يتضمن بعض العمليات العقلية المعرفية ومهارات التفكير (Costa \& Kallik, 2009. 1-7). وتعرف اجر ائيا بأنها القيم الفكرية التي تحكم وتوجه عمل العقل في بحثه عن المعنى فيما حوله من معلومات وخبرات، وتقاس بالدرجة التي يحصل عليها المتعلم في مقياس عادات العقل المعد لذلك.

\section{Visual Tinking التفكير البصري}

هو نمط من أنماط التفكير ينشأ نتيجة استثارة العقل بمثيرات بصرية يترتب عليها ادر اك المفاهيم و العلاقات في الشكل البصري، ويتم ذلك من خلال بجموعة من العمليات العقلية تترجم قدرة المتعلم على قراءة الشكل البصري، وتحويل اللغة البصرية إلى لغة لفظية مستخدما مهارات (التعرف و الوصف، والتحليل، وادراك العلاقات، والتفسير، واستخلاص المعني)، ويقاس بالدرجة التي يجصل عليها

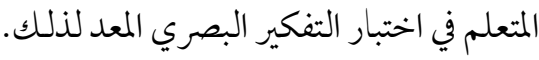


Historical Concepts المفاهيم التاريخية

يعرف المفهوم التاريخي بأنه "تجريد يستخلص من الخصائص أو العناصر المشتركة للمو اقف أو الأحداث أو الحقائق، ويتصف بالتعميم والتمييز والرمزية، وغالبا ما يعطى اسها أو رمزا، ويدل على الن الأفكار والمعاني التي تتكون في عقل الفرد" (خيري ابراهيم، 997 1، (Y9) ). ويعرف بأنه تجريد يعبر عنه بكلمة أو رمز يشير إلنا إلى مجموعة من الأشياء أو الأنواع التي تتميز

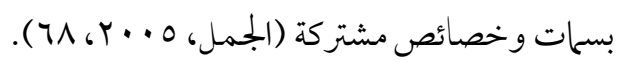

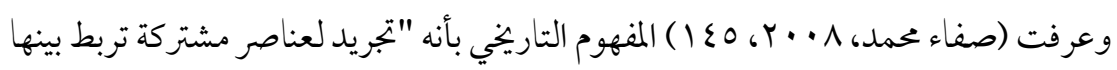
علاقات، ويرمز لهذا التجريد باسم أو رمز، ليدل علن الأحداث والوقائع التاريخية، وبناء علن ذلك فإن المفهوم ليس مجرد الكلمة أو الرمز ولكنه المدلول اللفظي أو مضمون تلك الكلمة في ذهن المتعلم ". ويعرف الباحث المفهوم التاريخي اجرائيا بأنه ما يتكون من معنى عند ادراك العلاقات بين الحقائق أو الأحداث التاريخية أو الظواهر أو الأشياء، وتنظيمه في أقل عددمن الكلمجات حسب الصفات أو الخصائص المشتركة التي تميزه عن غيره، والتأكيد علن الصفات المميزة وإهمال الصفات غير المميزة، ويقاس بالدرجة التي يجصل عليها الطالب في اختبار المفاهيم التاريخية المعد لذلك.

\section{فروض البحث}

ا. توجد فروق ذات دلالة إحصائية بين متوسطات درجات تلاميذ المجموعتين التجريبية والضابطة في التطبيق البعدي لاختبار المفاهيم التاريخية ومستوياته المختلفة لصالح تلاميذ المجموعة التجريبية. r. . توجد فروق ذات دلالة احصائية بين متوسطات درجات تلاميذ المجموعة التجريبية في التطبيق القبلي والبعدي لاختبار المفاهيم التاريخية ومستوياته المختلفة لصالح التطبيق البعدي. r. توجد فروق ذات دلالة إحصائية بين متوسطات درجات تلاميذ المجموعتين التجريبية والضابطة في التطبيق البعدي لاختبار مهارات التفكير البصري ومستوياته المختلفة لصالح تلاميذ المجموعة التجريبية. 
ع. توجد فروق ذات دلالة احصائية بين متوسطات درجات تلاميذ المجموعة التجريبية في التطبيق القبلي والبعدي لاختبار التفكير البصري ومستوياته المختلفة لصالح التطبيق البعدي. ه. توجد فروق ذات دلالة إحصائية بين متوسطات درجات تلاميذ المجموعتين التجريبية والضابطة في التطبيق البعدي لمقياس عادات العقل ومستوياته المختلفة لصالح تلاميذ المجموعة التجريبية. 7. توجد فروق ذات دلالة احصائية بين متوسطات درجات تلاميذ المجموعة التجريبية في التطبيق القبلي والبعدي لمقياس عادات العقل ومستوياته المختلفة لصالح التطبيق البعدي.

$$
\text { خطوات البحث واجر اءاته }
$$

للإجابة علن أسئلة البحث والتحقق من صحة فروضه اتبع الباحث الاجراءات التالية: ا. الاطلاع على الأدبيات والدراسات السابقة المتعلقة باستراتيجية الخرائط الذهنية، والمفاهيم

$$
\text { التاريخية، والتفكير البصري، وعادات العقل. }
$$

r. اختيار وحدتي (شخصيات وأحداث من التاريخ الفرعوني، مظاهر الحياة المصرية القديمة) من كتاب الدراسات الاجتماعية المقرر على تلاميذ الصف الرابع الابتدائي في الفصل الدراسي الثاني وتحليل محتو اها للتعرف علن المفاهيم التاريخية المتضمنة بها. r. اعداد دليل المعلم لتدريس وحدتي (شخصيات وأحداث من التاريخ الفرعوني، مظاهر الحياة المصرية القديمة) و فقا لاستراتيجية الخرائط الذهنية. ع. اعداد أدوات البحث وتشمل: اختبار المفاهيم التاريخية، اختبار التفكير البصري، مقياس عادات العقل والتأكد من صدق وثبات كل منها. ه. اختيار عينة البحث وتقسيمها إلى مجموعتين: تجريبية تدرس الوحدة وفقا لاستراتيجية الخرائط الذهنية، وضابطة تدرس الوحدة وفقا للطريقة المعتادة.

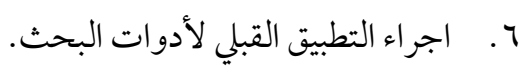
V . ت تدريس الوحدة للمجموعتين التجريبية والضابطة. 


$$
\text { A. اجراء التطبيق البعدي لأدوات البحث. }
$$

9 . رصد البيانات ومعالجتها احصائيا، التحقق من صحة الفروض، وتفسير نتائج البحث. • 1 ـ تقديم التوصيات والمقترحات في ضوء ما تسفر عنه نتائج البحث.

الإطار النظري

\section{أولا ـ استراتيجية الخر ائط الذهنية}

الفلسفة التي تقوم عليها الخر ائط الذهنية ( التعلم المستند إلى الدماغ ): في الربع الأخير من القرن العشرين بدأ الاهتمام بجانبي الدماغ من أجل التعلم والفهم القائم علن المعنى، وذلك من خلال التعرف على آليات عمل الدماغ بجانبيه لدعم نشاطات المتعلمين وتنمية قدراتهم العقلية في جانبي الدماغ (السلطي، ع • . r، Y ) فظهرت نظرية جديدة في التعلم هي نظرية التعلم المستند إلى الدماغ، التي اشتقت من عدد من العلوم منها الكيمياء، وعلم الأعصاب وعلم النفس، والهندسة الوراثية، والأحياء وعلوم الحاسوب (Jensen, 2000, 1) كما انها مدعومة بأبحاث

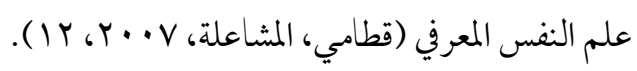

فالتعلم المستند إلى الدماغ هو تعلم وفقا للطريقة التي فطر عليها الدماغ، لكي يتعلم بشكل طبيعي، وهو العملية التي بواسطتها يستقبل الفرد ويعالج البيانات الحسية، ويرمزها داخل البنية المعرفية، ويحتفظ بها لحين استخدامها لاحقا، وكلما زاد فهم الأبنية المتضمنة وعمليات الدماغ، فإنه يمكن البدء بتطبيق تلك المعرفة لتحسين بيئات التعلم الفعال المتناغم مع الدماغ (السلطي، ع • . ب، • (1) لذا ينبغي على كل معلم أن يدرس آلية عمل الدماغ، ونظرية التعلم بجانبي الدماغ والاستراتيجيات التدريسية المنشطة للجانب غير المسيطر من الدماغ؛ وذلك من أجل رفع مستوكئ أداء

$$
\text { المتعلمين وتنشيط تفكيرهم و اثارته (عفانة، الجيش، } 1 \text { • • ؟ • (1). }
$$

وإذا كان التعلم وظيفة الدماغ البشري الطبيعية فإن نظرية التعلم المستند إلى الدماغ لها عددا من






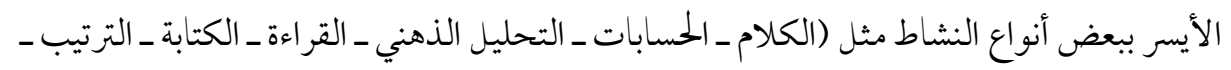


ـ العواطف ـ الانفعالات ـ الاستيعاب ـ الصور ـ الألوان القدرات الفضائية ـ الخيال) كما أنها يتكاملات في العديد من الأنشطة (الزيات، Y + . r) ويتصل نصفا الدماغ ببعضها) البعض من الداخل

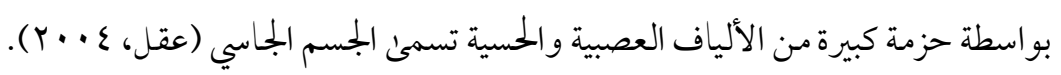

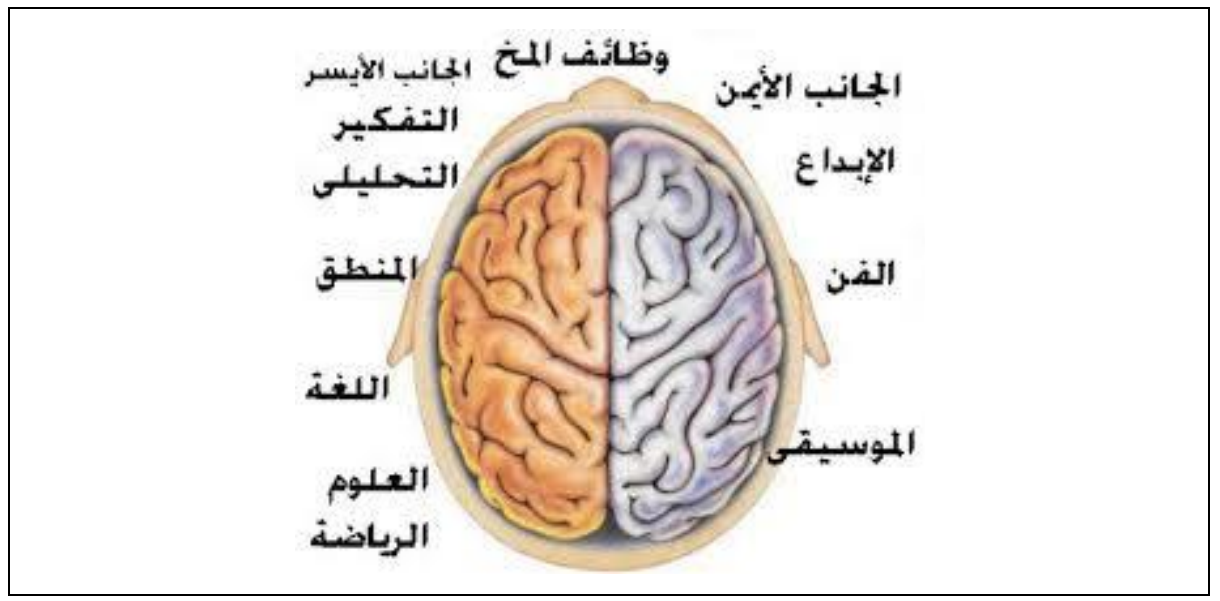

ويركن معظم المتخصصين في تربويات الدماغ أن معظم الأساليب و المو اد والممارسات الحالية قد صممت لتساير المتعلمين الذين يغلب عليهم استخدام الجانب الأيسر من الدماغ، فماذا عن المتعلمين الذين يغلب عليهم استخدام الجانب الأيمن من الدماغ ؟ واستجابة لذلك لابد من الأخذ في الاعتبار كلا النصفين في تصميم المناهج واستر اتيجيات التدريس والتقويم، وحتى في تنظيم وترتيب مو اصفات

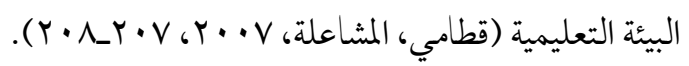

\section{نشأة استراتيجية الخرائط الذهنية}

تعد استراتيجية الخرائط الذهنية إحدى استراتيجيات التدريس القائمة علن التعلم المستند إلى إنى الدماغ، وأول من ابتكرها هو العالمتوني بوزان Tony Buzan في السبعينات من القرن العشرين، وهي تعمل على مبدأين أساسيين هما التخيل وتداعي الأفكار، وهي أداة فعالة للتفكير، لأنها تعمل مع المخخ 
وتشجعه علن خلق الروابط بين الأفكار، فهي عبارة عن إظهار مرئي للطريقة التي يفكر بها المخ، وهي تستخدم الحروف والأرقام كما تستخدم أيضا الألو ان والصور، وهذا يعني أنها تستخدم كلا نصفي المخ الأيمن والأيسر، فكل جانب من جانبي المخ يقوي الآخر ويستمد القوة منه بأسلوب يخلق امكانية غير

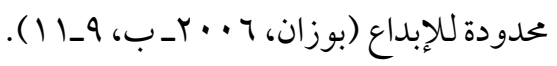
وتعتمد استراتيجية الخرائط الذهنية على رسم خريطة أو شكل يحاثل كيفية قراءة الذهن للمعلومات، حيث يكون المركز هو الفكرة الرئيسة، ويتفرع من هذه الفكرة فروع علن حسب الاختصاص أو التصنيف، ويمكن مقارنة الخرائط الذهنية بخر ائط المدينة، حيث أن مركز الخريطة الذهنية هو مثل مركز المدينة ويمثل الفكرة الأكثر أهمية في الموضوع الذي تتم دراسته، والطرق الرئيسة التي تتفرع من مركز المدينة تمثل الأفكار الرئيسة في عمليات التفكير، والطرق الثانوية أو التفرعات تمثل

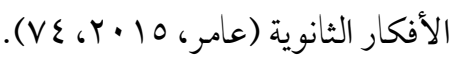
وتعتبر الخر ائط الذهنية احدى المنظمات التخطيطية التي تسهل الطريقة التي يتعلم بها المخ، فهي تقدم المواد التعليمية في شكل نهائي منظم، ولذلك فإنها تسمح بالترابط بين المعرفة السابقة والمعرفة الحالية، كما انها تساعد المتعلم على رؤية خريطته الحخاصة وهي بذلك تساعد على الإدر اك و الفهم المتميز كما أن التنسيق الرسومي للخريطة يسمح للمتعلم أن يستخدم اطار مكاني ليفهم ويوصل العلاقات بين المفاهيم (Ling, 2006,32)، وهي وسيلة ناجحة لتجميع المعلومات المقروة أو الخطط والأعمال المراد انجازها وربطها بواسطة رسوم وكلمات علن شكل خريطة، تساعد

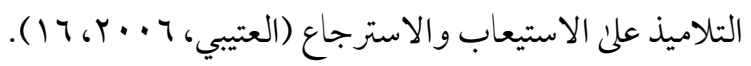
وهي استراتيجية يعمل بها العقل كوحدة واحدة يتناغم فيها النصف الأيمن مع النصف الايسر عن طريق تنظيم المحتوكي التعليمي بشكل غير خطى متشعب حول المفهوم الرئيسي ويعمل فروع منه بشكل متسلسل وفعال ليكون التعلم قويا ذا معنى، وتعد الخرائط الذهنية من الاستراتيجيات المهمة التي يجب استخدامها في المجال التربوي والتعليم لما لها من تأثير علن المتعلم يجعله يستمتع بالعملية 
التعليمية وهذا ينعكس علن الفهم والتحليل والتلخيص والتخيل للموضوع المراد تعلمة (عامر، .$(116 r \cdot 10$

\section{خطو ات رسم وإعداد الخريطة الذهنية}

تتكون الخريطة الذهنية من فكرة مركزية تكون في منتصف الورقة ويمكن أن يرسم المتعلم بجوارها صورة توضحها، ويخرج من هذه الفكرة المركزية فروع مائلة تسمى الأفكار الرئيسة، ويتفرع من هذه الفروع الرئيسة المائلة فروع أخرى تمثل الأفكار الفرعية أو الثانوية. ويمكن تلخيص خطوات رسم الخريطة الذهنية في الخطو ات التالية: ا. البحث عن الفكرة المراد رسمها بالخريطة الذهنية من مصادر التعلم (الكتب ـ المجلات

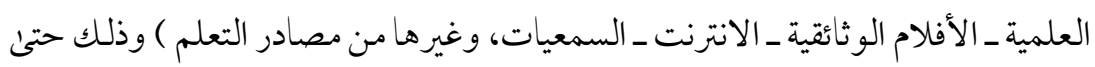
يمكن توثيق المعلومات وتدوينها بشكل علمي سليم، والمهارات المستخدمة خلال هذه

$$
\text { الخطوة هي (القراءة السريعة، والتركيز، والاستيعاب، والتلخيص ). }
$$

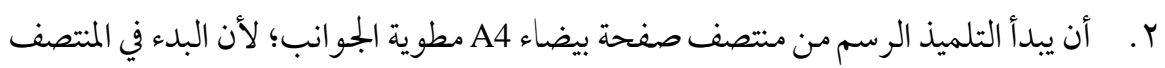
يعطي المخ الحرية للانتشار في جميع الاتجاهات، و التعبير عن نفسه بشكل طبيعي، وهو ما تقوم

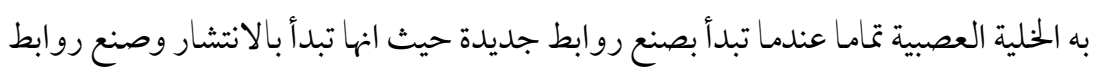

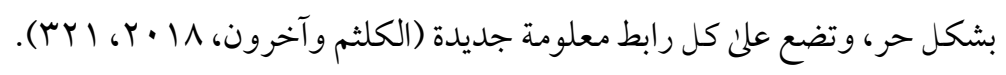

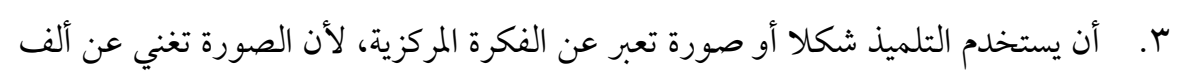
كلمة، وتساعد المتعلم على استخدام خياله.

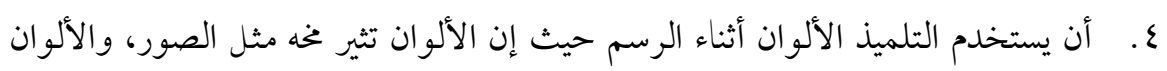
تضفي قدرا أكبر من الحياة على الخريطة الذهنية، وتضيف طاقة هائلة لتفكيره الإبداعي. ه. أن يصل المتعلم الفروع الرئيسة بالصورة المركزية، حيث إن المخ يعمل بالربط الذهني، فهو

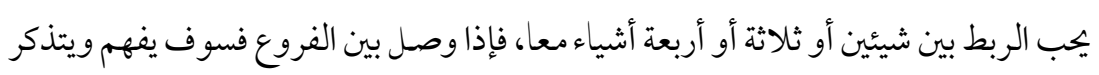

$$
\text { بسهولة شديدة. }
$$


7 . أن يجعل المتعلم الفروع متعرجة "ملتوية" وليست علن شكل خطوط مستقيمة، لأن الخطوط المستقيمة تصيب المخ بالملل، أما الفروع المتعرجة بشكل طبيعي فتتميز بالمرونة والسماحة

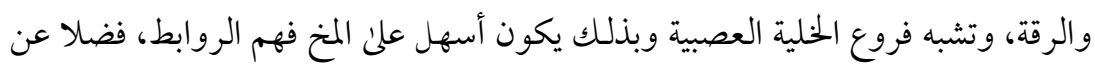
كونها أكثر جاذبية وإبهار للعينين. V. أن يستخدم التلميذ كلمة مفردة في كل سطر، فإذا لم تعبر هذه الكلمة عن المضمون المطلوب، فيمكنه استخدام كلمتين أو أكثر بحيث تعبر عن المضمون، لأن استخدام كلمات رئيسة مفردة تمنح الخريطة الذهنية القوة والمرونة، وكل كلمة مفردة تولد سلسلة من الروابط والعلاقات الذهنية. ^. أن يستخدم التلميذصورا عند رسم الفروع، "إذا كان بالموضوع صورا تعبر عنه" لأن كل صورة تغني عن ألف كلمة، لذلك إذا كان لديه عشرة صور علئ الخريطة الذهنية الخاصة به

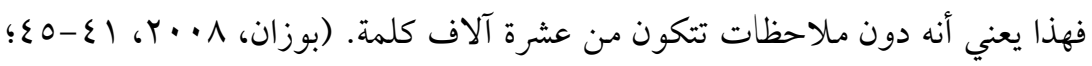

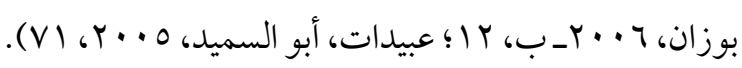
9 . بعد أن ينتهي المتعلم تماما من وضع كل أفكاره وأفكار الآخرين في الخريطة الذهنية يكون عليه اعادة النظر اليها نظرة متفحصة والقيام بترتيبها. أمور يجب علن المتعلم وضعها في الاعتبار وإرشاد وتوجيه التلاميذ إليها عند رسم الخريطة الذهنية: لا تتقيد بشكل محدد، يمكنك أن تخترع نظاما شكليا خاصا بك، النقطة المهمة أن تكون الأفكار متصلة ببعضها البعض، متفرعة من بعضها البعض. إذا مر عقلك بحالة تجمد، وشعرت بتباطؤ تدفق الأفكار، أو أنه لا يوجد لديك مزيد من الأفكار لتضيفها فلا تفزع وابق يدك في حالة حركة مستمرة، ارسم دوائر وأفرع فارغة، أو ارسم خطوطا جديدة علن الخطوط الموجودة أصلا، أو قم يتغيير اللون؛ فمثل هذا يساعد علن. شحن طاقة المخ، ويدفعه لانتاج المزيد من الأفكار. 
إذا وجدت وأنت تكتب علاقة بين الأفرع المختلفة بشكل فوري، أو وجدت فكرة واحترت في الفرع الذي يجب أن تضع الفكرة تحته، فلا تعيد بناء ما كتبت؛ فالترتيب يبطئ تدفق أفكارك، ستقوم بترتيب أفكارك لاحقا، يمكنك وضع علامة سريعة، وتذكر أنه يمكنك دائما

ادراج الأفكار مباشرة تحت النقطة المركزية الرئيسة دون أن تضيع الوقت في تنظيمها. العقول البشرية ختلفة عن بعضها البعض، فقد يكون هناك اختلاف طرق التخطيط لنفس الموضوع من قبل البعض، وهذا يجعل في الو اقع ما تقدمه شيئا متجددا وجميلا في كل مرة. حاول ـ قدر الاستطاعة ـ أن تظهرها بأسلوب فني، مرح، وشخصي.

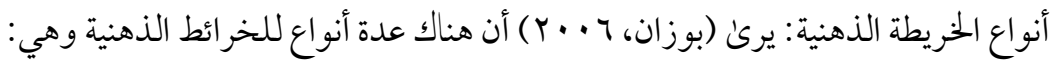
1- الخر ائط الذهنية الثنائية: وهي التي تحتوي فرعين متشعبين من المركز. r- الخرائط الذهنية المركبة أو متعددة التصنيفات: تشمل أي عددمن الفروع الأساسية، يتراوح من ثلاثة إلى سبعة، حيث ثبت من خلال التجربة أن العقل المتوسط لا يستطيع أن يحمل أكثر من سبع مفردات أساسية من المعلومات، أو سبعة بنود في الذكرة قصيرة المدىن، ومن أهم

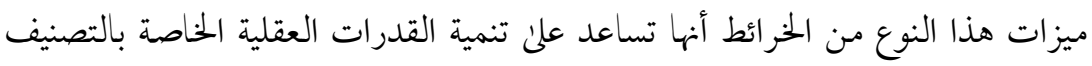
والوضوح والدقة. ץ- الخر ائط الذهنية الجلماعية: يقوم بتصميمها عدد من الأفراد معا في شكل بجموعات، وأهم ما


مستقل، ثم يتم بعد ذلك تكامل للأفكار لإخراج خريطة ذهنية جماعية ميزة. ع - الخرائط الذهنية المعدة باستخدام الكمبيوتر : يمكن استخدام الكمبيوتر في تصميم الخرائط الذهنية، حيث توجد عدة برامج تساعد في إعداد وتصميم الخرائط الذهنية منها Free Mind. 
تتميز الخرائط الذهنية بوضوح الفكرة الرئيسة في الموضوع، وربط الفكرة الرئيسة بالأفكار والموضوعات بصورة متتابعة تتميز بالنهايات المفتوحة التي تسمح للعقل أن يعمل اتصالات جديدة بين الأفكار تساعد على الاستدعاء والمر اجعة للأفكار والموضوعات بصورة شاملة وفعالة. كما أن للخرائط الذهنية عدة مميزات منهامراعاة الفروق الفردية، وتنمية مهارات التفكير، تحفز علن الإبداع وتنشط الذهن، وتشوق المتعلم للمادة التعليمية وتشجعه علن توليد الأفكار والأراء الجديدة، وتنمي قدرته علن توظيف مهارات الرسم والإخراج بشكل جيد، مما يساعد المتعلم علن تذكر الأفكار المهمة وتزيد من ثقته بذاته وبالتالي ترفع مستواه التحصيلي كما أن استخدامها يؤدي إلى حفظ المعلومات لمدة أطول وتوجه المتعلمين إلى ضرورة استكمال النقص في المعلومات إن وجد (محمود . $(r \cdot r: Y \cdot T$

\section{استخدام الخرائط الذهنية في تعليم التاريخ}

يتيح استخدام استراتيجية الخرائط الذهنية فرصة تنفيذ عدد كبير من الأنشطة في الموقف التعليمي: ا - النظرة: من خلال تكوين النظرة التحليلية والشمولية المتكاملة عن الموضوعات الدراسية. r- الشرح: تعد وسيلة فعالة في شرح المفاهيم والنظريات والمبادئ والقيم والمهارات والأفكار

$$
\text { المتضمنة في الموضوع الدراسي. }
$$

r- التدوين: تعد أداة فعالة في تدوين الملاحظات و التعليمات والخطو ات وتنظيمها خلال حضور

$$
\text { الحصص والندوات والمؤتمرات بشكل يسهل تذكرها. }
$$

ع - الإظهار : تعد أداة فعالة في إظهار وكشف العلاقات و الرو ابط و الأفكار و القضايا المتضمنة في

$$
\text { الموضوع الدراسي. }
$$

0- الاستمطار : تعد أداة قوية في استمطار الخبرات والأفكار ذات العلاقة بالموضوع.


عن كافة المعلومات التي يجب الاهتحام بها عند دراسة هذا الموضوع وتنظيمها بسهولة.

\section{http://dx.doi.org/10.29009/ijres.3.3.10}


V- التنظيم: عند جمع كم كبير من المعلومات والأفكار عن موضوعات دراسية فإن الخرائط الذهنية تساعد في ترتيب هذه المعلومات والأفكار وترتيب أولوية معالجتها. 1- المراجعة: تساعد الخرائط الذهنية التلاميذ في عمل مراجعات قوية وسريعة استعدادا

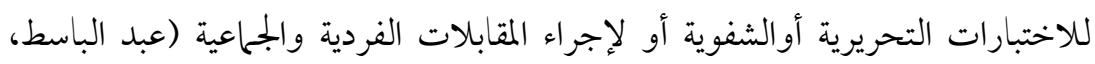
( $(\varepsilon: Y \cdot) \varepsilon$

وفي إطار الاهتحام باستراتيجية الخر ائط الذهنية فقد أجريت العديد من البحوث والدراسات

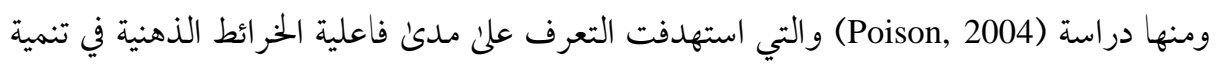

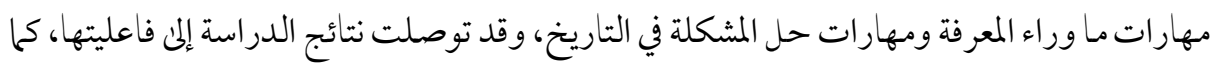
أشارت نتائجها إلى تقبل المتعلمين لها.

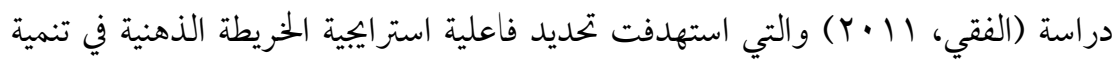

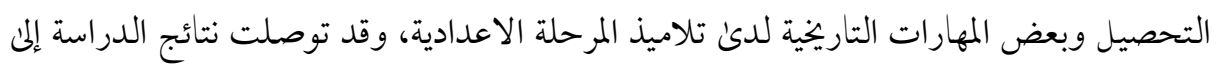
فاعلية الخرائط الذهنية في تنمية التحصيل والمهارات التاريخية لدئ عينة الدراسة.

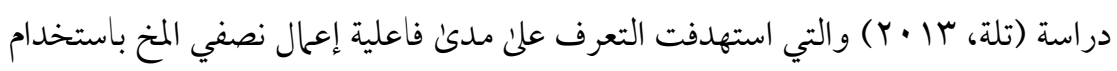

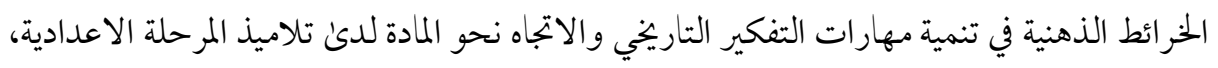

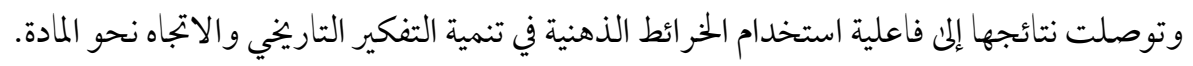




ذات دلالة احصائية بين متوسطات درجات المجموعة التجريبية والمجموعة الضابطة في التطبيق البعدي للاختبار التحصيلي لصالح المجموعة التجريبية.

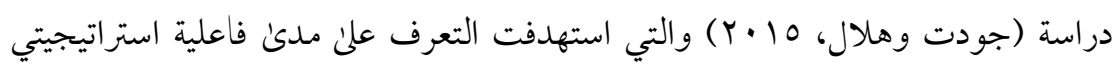

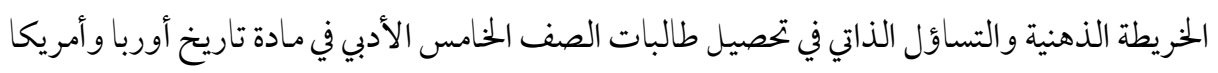


الحديث والمعاصر، وقد أشارت نتائجها إلن أن استراتيجيتي الخريطة الذهنية والتساؤل الذاتي أثبتـا فاعليتها في تدريس التاريخ للطالبات. دراسة (يو سف، 10 (Y) و التي استهدفت تحديد فعالية استراتيجية الخرائط الذهنية في تدريس

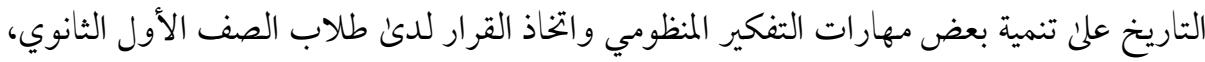
والتي أثتتت فاعلية الخر ائط الذهنية في تنمية التفكير المنظومي واتخاذ القرار لدئ الطلاب.

Habits of Mind ثانيا ـ عادات العقل

اشتق مفهوم عادات العقل من اطار نظري كبير مكون من مجموعة من النظريات المعرفية أهمها

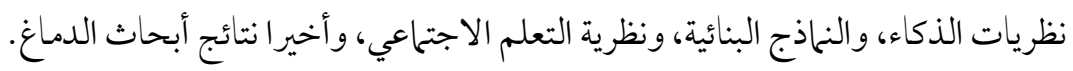
وقد تعددت تعريفات عادات العقل بتعدد وجهات النظر، فمنهم من يرئ أنها: نزعة الفرد إلى النى

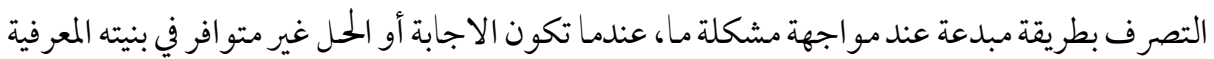

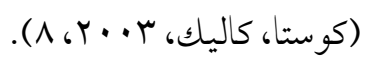

كما انها العادات التي تدير وتنظم وترتب العمليات العقلية، وتضع نظام الأولويات السليم

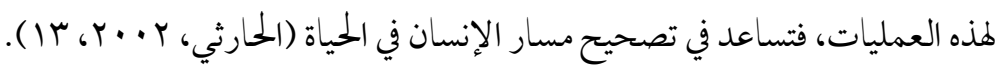
وتعرف أيضا بأنها تفكير منظم مرتب يتضمن آليات واستراتيجيات متصلة بهدف تم التخطيط

$$
\text { لتحقيقه بوعي (قطامي، V. V. T، ع ( ). }
$$

وفي ضوء ما سبق يمكن القول أن عادات العقل هي: مهارة المتعلم في تنظيم أفكاره وترتيبها


التي تواجهه في حياته اليومية.

$$
\text { تصنيف عادات العقل }
$$

قدم هايرل (Hyerle, 1999) تقسيم لعادات العقل تضمن ثلاثة أقسام: الأول خرائط




العصف الذهني ويتفرع منها: الابداع والمرونة وحب الاستطلاع، وتوسيع الخبرة، والثالث منظمات الرسوم ويتفرع منها: المثابرة، والتنظيم، والضبط، والدقة.

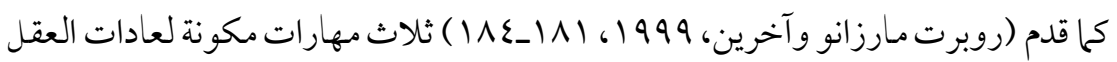
هي: مهارة تنظيم الذات، ومهارة التفكير الناقد، ومهارة التفكير الابتكاري. وقدم (Costa\& Kallick, 2000) ستة عشر عادة عقلية هي: المثابرة، التحكم بالتهور، الاصغاء بتفهم، التفكير المرن، التفكير فوق المعرفي، الكفاح من أجل الدقة، التساؤل وطرح المشكلات، التفكير التبادلي، تطبيق المعرفة السابقة في مواقف جديدة، التفكير والتواصل بوضوح ودقة، جع البيانات باستخدام الحواس، الابداع والتخيل والابتكار، الاستجابة بدهشة، تحمل المسؤولية والمخاطرة، ايجاد

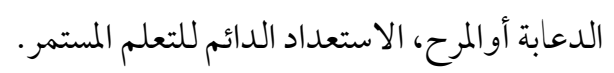
وباستقر اء التصنيفات السابقة يلاحظ أن هناك تشابه بينها في بعض عادات العقل، مثل: حب الب الم الاستطلاع، المرونة، الدقة، الابداع، المثابرة، التنظيم، ما وراء المعرفة، طرح المشكلات.

\section{عادات العقل وعلاقتها بالخر ائط الذهنية}

يمكن أن يسهم استخدام الخر ائط الذهنية في التدريس في تنمية عادات العقل؛ باعتبار ها المرآة الخارجية للتفكير المرن، الذي يعكس العمليات الداخلية للعقل، فهي أداة بصرية ولفظية تستخدم بطريقة مرنة واشعاعية أثناء حل المشكلات الابداعية (Victor \& Valqui, 2006) كما أنها النظام الذي من شأنه توسيع مجال استخدام الفرد للغة والألفاظ والصور؛ بهدف التذكر والتفكير الابداعي وحل

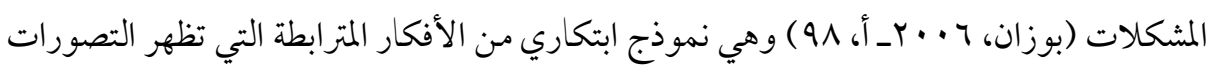

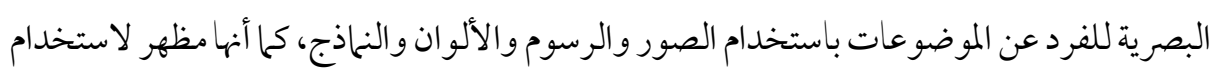
كل من النصفين الأيمن والأيسر (Trevino, 2005, 34). ويؤكد توني وباري بوزان أن الخرائط الذهنية مظهر خارجي وفريد لكل مراحل الابتكارية فيمكن أن نعطي للتلاميذ الفرصة ابتكار خر ائطهم العقلية، بعد تتبعهم (Buzan, T. \&., 1994, 155)




N. E. صغيرة، ثم يتم اختيار تلميذ من كل بجموعة لمشاركة الخريطة العقلية الخاصة به مع الفصل كله (A., 2007

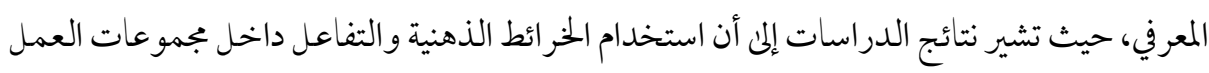
يساعد علن النمو العقلي (Oldfather, et al., 1994, 15-25). كما أن الخرائط الذهنية من الاستراتيجيات التي تستخدم للتعرف على المعلومات القبلية، وتساعد التلاميذ علن تمثيل واستيعاب المعلومات الجلديدة وتطوير خخططاتهم المعرفية للمفاهيم (Evrekli, et al., 2009, 2274) بالترابط بين المعرفة السابقة والمعرفة الحالية، وتساعد المتعلم علن رؤية خريطته الخاصة .(Cunningham, 2005, 59) كما أنها أداة معرفية تساعد في تعزيز عمليات ما وراء المعرفة؛ حيث تسمح للتلميذ بتخيل Jones, B. et al., 2012, 5, ) المفاهيم وتطوير بنيته المعرفية، وتوضح التغير المفاهيمي لدىن التلاميذ (Zumback, 2008 وتساعد علن تسجيل الملاحظات، والعصف الذهني للأفكار وحل المشكلات، والتخطيط والتدريس والتو اصل و استراتيجيات ما وراء المعرفة (Mackelbergh, 2006). يتضح مما سبق ان استخدام الخرائط الذهنية في التدريس يمكن أن يساعد في تنمية بعض عادات العقل مثل: المرونة في التفكير، التفكير فوق المعرفي، التفكير التبادلي، التفكير الابتكاري، تطبيق المعرفة السابقة في مواقف جديدة، التخيل، حل المشكلات، التنظيم، جمع البيانات باستخدام الحواس، تحمل المسئولية، وقد اقتصر البحث الحلالي علن قياس أربعة من هذه العادات وهي: (المثابرة ـ الإصغاء بتفهم وموضوعية ـ التفكير بمرونة ـ التساؤل وطرح المشكلات ) حيث إنها أكثر ارتباطا باستخدام الخر ائط 
ثالثا: التفكير البصري Visual Thinking إن أكثر عمليات التفكير أهمية تأتي مباشرة من ادر اكنا للعالمرن حولنا، حيث يكون البصر هو الجهاز الحسي الأول الذي يوفر أساس عملياتنا المعرفية وتكوينها، فعملية الابصار واستخدام حاسة البصر، وتنمية المهارات البصرية لها دور أساسي في عملية التعلم.

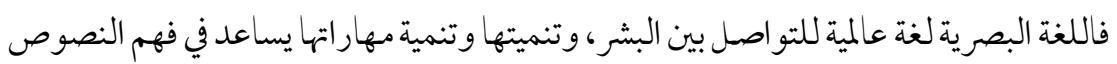
المكتوبة، وينمي القدرة علن التفكير وادراك العلاقات، ولكي يتمكن التلميذ من ذلك عليه ممارسة


ويعد التفكير البصري نمط من أنهاط التفكير الذي يعتمد علن الرؤية، وعادة ما يتأثر باللغة

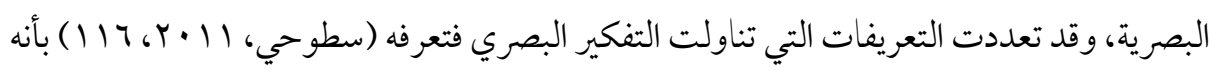
نمط من أنماط التفكير علي المستوكن ينشأ نتيجة استثارة العقل بمثيرات بصرية يترتب عليها ادراك مفهوم أو علاقة لنموذج أو شكل ما، ويتم ذلك من خلال بجموعة من العمليات العقلية، متمثلة في قدرة المتعلم على أن يترجم اللغة البصرية إلى لغة رياضية.

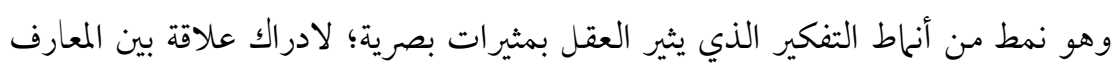

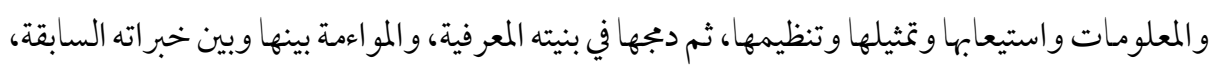

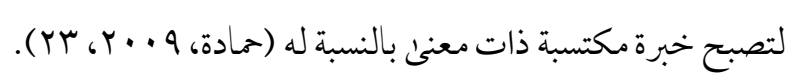
بينما يعرفه آخرون بأنه منظومة من العمليات تترجم قدرة الفرد على قراءة الشكل البصري،

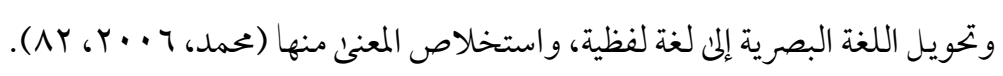

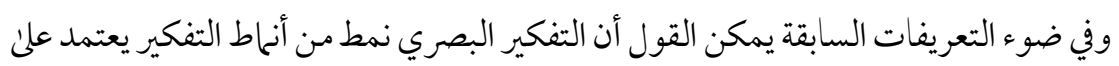
اثارة العقل باستخدام مثيرات بصرية، ويتضمن بجموعة من العمليات متمثلة في قدرة المتعلم علن تحويل اللغة البصرية إلى لغة لفظية أو رياضية. 


\section{مهارات التفكير البصري}

يتضمن التفكير البصري مجموعة من المهارات تترجم قدرة المتعلم علن قراءة الشكل البصري وتحويل اللغة البصرية إلى لغة لفظية، وهذه المهارات يمكن تحديدها في ثلاث مهارات رئيسة هي: الملاحظة البصرية، والمقارنة البصرية، والتخيل البصري، وتشمل كل مهارة رئيسة عددا من المهارات

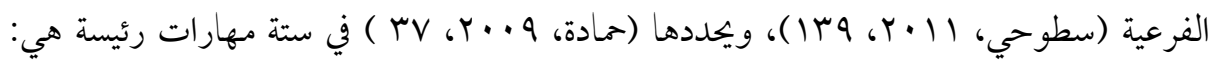
التوصيف، والتفسير، وادراك العلاقات، والتمثيل، والاستنتاج، والتبرير، كما تحددها (الخزندار،

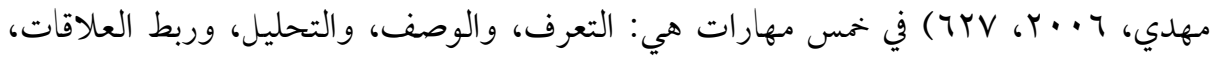

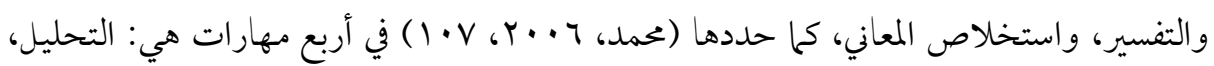
والتركيب، والإدراك، والنظرة الشمولية الكلية. باستقراء مهارات التفكير البصري السابقة نجد أن معظمها يتفق علن مهارات: التعرف والوصف، والتحليل، وادراك العلاقات، والتفسير، واستخلاص المعني، وقد اتخذ الباحث هذه المهارات الخمس أبعادا لاختبار التفكير البصري. أهمية تنمية التفكير البصري لدى تلاميذ المرحلة الابتدائية ترجع أهمية تنمية التفكير البصري لدئ التلاميذ في أنه يساعد علن تصنيف الأشياء وسهولة استخدامها، فهو يعتمد علن تنوع التقنيات والصور في تمثيل الأفكار باستخدام الكلمات والرموز، وتبادل المعلومات بطريقة سريعة ومؤثرة، ويسهم في ايجاد العلاقات بين الموضوعات والمفاهيم والأفكار، مما يمكن من فهمها (Buzan, 2000). كما أنه يسهم في زيادة التفاعل والنشاط أثناء عملية التعلم، والتوصل إلى أفضل الأساليب للتو اصل مع الآخرين، وتبادل الأفكار، والتمكن من التعامل مع المشكلات الطارئة وحلها، وزيادة

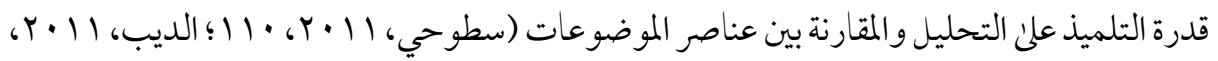


وتساعد الخر ائط الذهنية في تنمية التفكير البصري من خلال الامكانات المتاحة في الرسوم التي

تعبر عن الكثير من المعاني المتعلقة بمفهوم ما (Anderson, 1997). فالخر ائط الذهنية تعتمد على التفكير البصري الذي يقوم علن ترتيب الأشياء مكانيا في الفراغ، فهي تشخيص للتصورات البصرية للتلميذ عن الموضوعات باستخدام الصور والرسوم والألوان، وهي من الاستراتيجيات المناسبة لتلاميذ المرحلة الابتدائية لاعتمادها علن الرسوم والصور والألوان، كما أنها تقابل الفروق الفردية للتلاميذ، وتسمح بالاتصال والتواصل والتعلم النشط الفعال، فتلميذ المرحلة الابتدائية يمتاز بذاكرة بصرية، ولديه القدرة على التخيل والاسترجاع وادراك العلاقات، كعلاقات الزمان والمكان، والتشابه والاختلاف.

\section{التفكير البصري وعلاقته بالخر ائط الذهنية}

الخريطة الذهنية من أدوات التفكير البصري كونها تمثل لغة بصرية مشتركة بين المعلم والمتعلم، علن اعتبار أنها أسلوبا جديدا لتنظيم المعلومات في بنية المتعلم، ويقوم علن استعمال الخرائط التي تنتظم عن طريقها الأفكار المهمة لأي موضوع دراسي يدرس إذ تسهل علن المتعلم استرجاعها وتفسيرها وتحليلها (خليل، • ( •r: باتح).

رابعا ـ المفاهيم التاريخية Historical Concepts تعد المفاهيم من أهم نواتج التعلم التي بواسطتها تنظم المعرفة في صورة ذات معنى، فهي الوحدات البنائية للعلم، وعن طريقها يتم التو اصل بين الأفراد. وقد تعددت تعريفات المفاهيم؛ فيعرف المفهوم بأنه صورة ذهنية تدل علن بجموعة من الأشياء أو الأحداث أو الأشخاص التي تشترك في خاصية واحدة أو أكثر تميزها عن غيرها، ويعبر عنها بكلمة

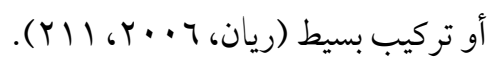
ويعرف بأنه تجريدا عقليا للصفات المشتركة لمجموعة من الأشياء أو الخبرات أو الظواهر




ويعرف المفهوم التاريخي بأنه تصور ذهني ذي طبيعة متغيرة يقوم علن ايجاد علاقات بين الأشياء

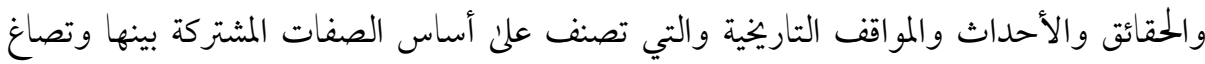



و المفهوم التاريخي عبارة عن صورة عقلية عامة تكون علن شكل كلمة ججردة أو شبه جملة تشير

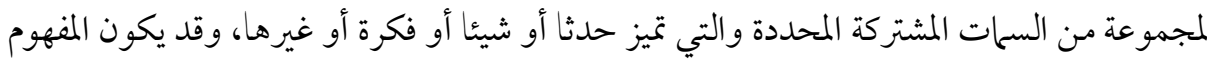



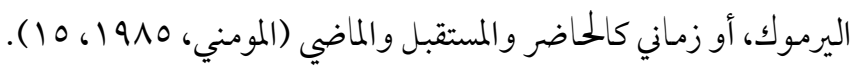

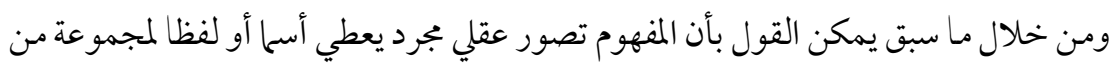

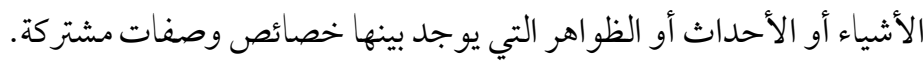

\section{طبيعة وخصائص المفاهيم التاريخية}

المفهوم التاريخي ليس خبرا أو حدثا تاريخيا معينا، وإن كان ينطوي علن أخبار وأحداث تاريخية

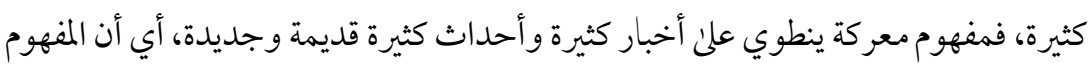
التاريخي قاعدة معرفية يمكن تحديدصفة تصنيفية معينة له.



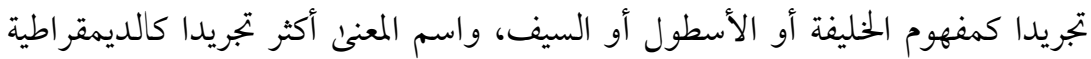

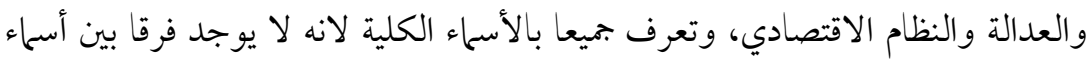

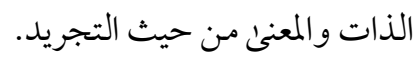
المفهوم التاريخي قد يكون مرتبط بقواعد اقترانية أو قواعد انفصالية فمفهوم النظام الاقتصادي مقترن بالزراعة والصناعة والتجارة والصيد والضرائب...الخ، ومفهوم الصليبين يرتبط بقاعدة انفصالية فالصليبين قد يكونوا فرسان أو أمراء أو محاربين أو ملوك 
أوربا، والسلاح مرتبط كذلك بقاعدة انفصالية فالدبابة سلاح، والطائرة سلاح، والسيف

$$
\text { سلاح، والقنبلة سلاح....الخ. }
$$

قد تكون المفاهيم وصفية أو قيمية، وصفية كمفهوم ديكتاتور، وقيمية كالعبودية والحرية. المفهوم التاريخي مدرك، ووجوده ذهني عقلي مجرد أي ليس له حقيقة مستقلة عن تصور العقل

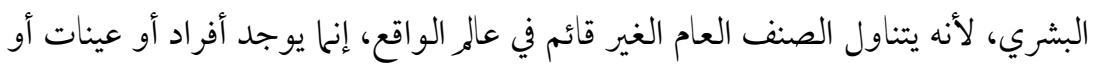
نماذج تدل عليه أو تعادله وهذه ترتبط مع بعضها بخصائص وصفات مشتركة ليكون المفهوم

$$
\text { مثثلا لهذه العينات أو النماذج أو الأفراد. }
$$

المفاهيم التاريخية قد تكون عامة أو أساسية يمكن اشتقاق مفاهيم تاريخية فرعية منها، كما يمكن اشتقاق مفاهيم متفرعة من الفرعية أي من حيث التعميم والتخصيص والأكثر

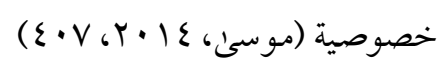

\section{أنواع المفاهيم التاريخية وتصنيفاتها}

تصنف المفاهيم التاريخية بطرق شتى أفضلها أن تصنف حسب الدور الذي تلعبه في التعلم، فبعض المفاهيم تبدو أكثر فائدة من غيرها، وبعض المفاهيم لا فائدة منها بسبب اتساعها وشمولها، ويمكن تحديد المفاهيم التاريخية في الأنواع التالية:

ا ـ مفاهيم الوقت: وتنقسم إلى مفاهيم الوقت المحدد لشيئ ما والمرتبط بنقطة بداية، مثل الساعة

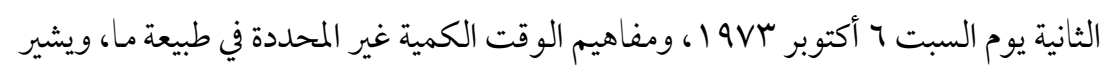
إلم استغراق الوقت مثل: قرن، عصر، الليل والنهار، ومنذ وقت قريب، والعصور

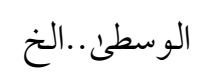

r r . مفاهيم المكان: مثل: عاصمة، شبه جزيرة، الهضبة، الجبل.


بحيرة، جزيرة، غابة. 
ع. المفاهيم المحددة: وهي أكثر تجريدا وصعوبة مثل الديمقراطية، والتعاون، والاحترام، والحرية.

ه. المفاهيم الجلديدة: وهي المفاهيم التي ظهرت حديثا نتيجة للتقدم العلمي أو الأحداث التاريخية المستجدة كالطاقة الذرية، الأقمار الصناعية، الوطن السليب، عدم الانحياز، العولمة،

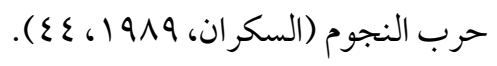

\section{مستويات المفاهيم التاريخية وتطورها}

المفاهيم تبدأ بدايات صغيرة وبشكل تدرييي، فالطفل لا يجصل علن مفهوم فرعون إلا بعد

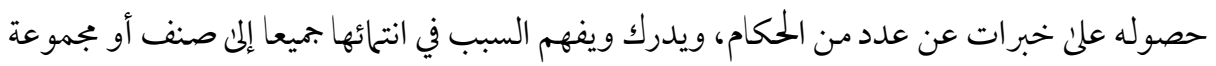

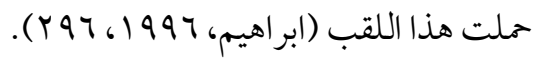
ونمو المفاهيم وتطورها لا يتم علن وتيرة واحدة أو بمعدل واحد، وانما تختلف درجة نموها وتطورها باختلاف المفهوم نفسه، فالمفاهيم المادية تتطور بدرجة أسرع من المفاهيم المجردة، وقد يعود ذلك إلى استخدام الحبرات المباشرة والأمثلة الحسية في تشكيل المفاهيم المادية وتعلمها، وهذا لا يتوفير في تشكيل المفاهيم المجردة، وانما يتشكل بالاعتماد علن الخبرات البديلة والأمثلة الرمزية، ولعل الخرائط

$$
\text { الذهنية احدى الاستراتيجيات التي يمكن أن تسهم في تعلم المفاهيم التاريخية. }
$$

وتتطور المفاهيم التاريخية من البسيط إلى المعقد، ومن المحسوس إلى المجرد، ومن التشابه إلى بلى

التباين، ومن التجزئة إلى التعميم، ومن المتمركز حول الذات إلى الشعور الاجتماعي.

$$
\text { أهمية تعلم المفاهيم التاريخية }
$$

إن تعلم المفاهيم التاريخية أحد الأهداف الأساسية لتدريس التاريخ في جميع مراحل التعليم،

$$
\text { حيث إن تعلم المفاهيم بطريقة فعالة يساعد علن التعلم الناجح. }
$$

ويقصد بتعلم المفهوم أي نشاط يتطلب من المتعلم أن يجمع بين شيئين أو حادثين أو أكثر من

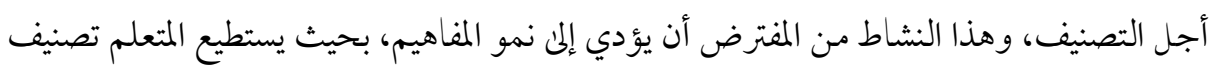


الأشياء الجحيدة تصنيفاصحيحا، بصورة تمكنه من التفرقة بين الأمثلة الموجبة والسالبة (زياد، ه · ؟ ،

وفي حالة قيام المعلم بتعليم مفهوم معين لتلاميذه فإنه يجب عليه تقديم النشاط التعليمي الذي يشتمل علن أمثلة المفهوم الموجبة والسالبة، فإذا تمكن التلميذ من تصنيف المثيرات باختيار الأمثلة

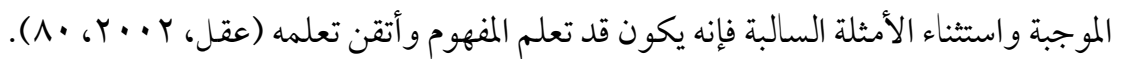

مستويات تعلم المفاهيم ميز كلاوزمير (klausemier, 1980, 37) بين مستويين في تعلم المفاهيم: أ- المستوئ الأدنى: ويتمثل في قدرة الفرد علن التمييز بين الأمثلة المطابقة والأمثلة غير المطابقة

$$
\begin{aligned}
& \text { للمفهوم. } \\
& \text { ب- المستويات العليا: ويتمثل تعلم المفاهيم فيها يلي: } \\
& \text { • تعريف المفهوم بخصائصه المحددة. }
\end{aligned}
$$

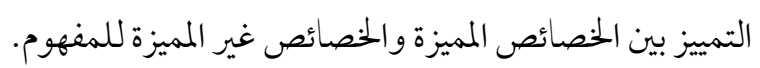

التمييز بين الأمثلة المطابقة والأمثلة غير المطابقة على أساس الخصائص المحددة للمفهوم.

$$
\begin{aligned}
& \text { • تحديد المفاهيم العليا التي يندرج تحتها المفهوم والمفاهيم الدنيا التي تندرج تحته. } \\
& \text { • تحديد المبدأ الذي يربط المفهوم بمفهوم أخر أو أكثر. }
\end{aligned}
$$

وقد استخدم الباحث هذه المستويات وما يندرج تحتها كمعيار لقياس مدئ تعلم تلاميذ الصف الصف الرابع الابتدائي لمستويات تعلم المفاهيم التاريخية المتضمنة بوحدتي "شخصيات وأحداث من التاريخ الفرعوني، مظاهر الحضارة المصرية القديمة" كدليل علن تنمية المفاهيم التاريخية لديهم.

$$
\text { تقويم تعلم المفاهيم }
$$

لتقويم مستويات تعلم المفاهيم وفقا لنموذج كلاوزمير (klausemier) وضع "فراير" وآخرون

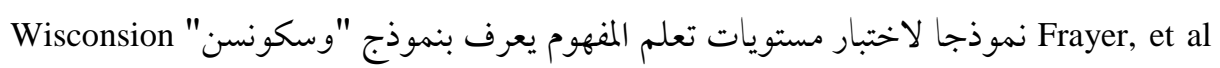


ويقيس مستويات تعلم المفهوم من خلال عشر مهام، اثنان منها تثثل المستوئ الأدني وثمانية منها تثثل

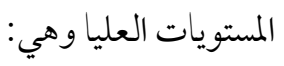
1. اعطاء اسم المفهوم، ويختار التلميذ المثال الموجب للمفهوم. r. . اعطاء اسم المفهوم، ويختار التلميذ المثال السالب للمفهوم. r. اعطاء المثال الموجب للمفهوم، ويختار التلميذ اسم المفهوم. ع. اعطاء اسم المفهوم، ويختار التلميذ الخاصية المميزة للمفهوم. 0. اعطاء اسم المفهوم، ويختار التلميذ الخاصية غير المميزة للمفهوم. 7. اعطاء معنى المفهوم، ويختار التلميذ اسم المفهوم.

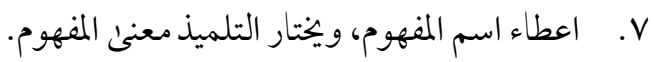
^. اعطاء اسم المفهوم ويختار التلميذ المفهوم الأعلى. 9 . . اعطاء اسم المفهوم ويختار التلميذ المفهوم الأدنى.

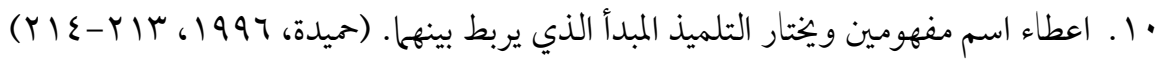
وقد استخدم الباحث هذه المهام لقياس مستويات تعلم المفاهيم التاريخية المتضمنة بوحدتي "شخصيات وأحداث من التاريخ الفرعوني، مظاهر الحضارة المصرية القديمة" لدئ عينة البحث.

\section{المفاهيم التاريخية وعلاقتها بالخر ائط الذهنية}

يرئ الباحث ان الخر ائط الذهنية يمكن أن تقدم مفتاح للمفاهيم المتضمنة بالموضوعات الصعبة و تسلسل منطقي للعلاقات المرتبطة بينها في تصميم جذاب يوضح المستويات المختلفة ليسهل الوصول لفهم عميق وتجهيز معلومات للمستويات العليا من التفكير كالتطبيق والتركيب والتقويم (صلاح الدين، 11 + r، (1). 




اختار الباحث وحدتي "شخصيات وأحداث من التاريخ الفرعوني، مظاهر الحضارة المصرية القديمة" المقررتين علن تلاميذ الصف الرابع الابتدائي في منهج الدراسات الاجتهاعية بالفصل الدراسي

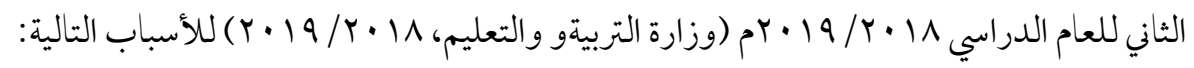
ا. أنها يتضمنان العديد من الشخصيات والأحداث، فضلا عن الأشطة التي يقوم التلاميذ بأدائها، ويمكن من خلالها تنمية المفاهيم التاريخية وممارسة بعض عادات العقل. r. . تشتمل الوحدتان على العديد من الموضوعات المهمة التي تساعد التلميذ علن تكوين تصور

$$
\text { سليم عن العصر الفرعوني بملوكه والانجازات التي تحققت فيه. }
$$

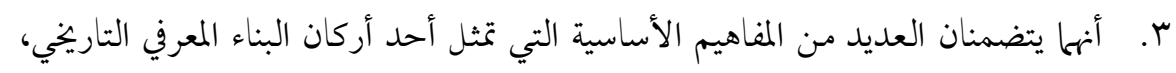
ويجتاجها التلميذ في المراحل التعليمية الأعلى.

ع. زمن تدريس الوحدتين كبير، مما يمكن أن يسهم في تنمية بعض عادات العقل وبعض مهار ات

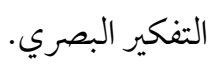

ه. تتضمن الوحدتين العديد من الأفكار والمفاهيم الرئيسة والفرعية التي يمكن أن يستخدمها

$$
\text { التلميذ في اعداد ورسم خر ائط العقل. }
$$

7 . تتيح موضوعات الوحدتين الفرصة أمام التلاميذ لتصميم العديدمن الخر ائط العقلية المتنوعة

$$
\text { التي يمكن أن تسهم في تنمية مهار ات التفكير البصري. }
$$


تم اعداد وحدتي "شخصيات وأحداث من التاريخ الفرعوني، مظاهر الحضارة المصرية

$$
\text { القديمة" باتباع الخطوات التالية: }
$$

تم تحديد الأهداف العامة من دراسة وحدتي"شخصيات وأحداث من التاريخ الفرعوني،

مظاهر الحضارة المصرية القديمة" بالاستعانة بالأهداف المحددة لهم) في كتاب التلميذ (وزارة التربية

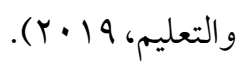

$$
\text { r- تحليل محتوئ الوحدة }
$$

تم تحليل محتوىن وحدة "مظاهر الحضارة المصرية القديمة" لتحديد المفاهيم التاريخية المتضمنة بها، ولحساب ثبات التحليل أجرىن الباحث عملية التحليل مرتين بفارق زمني قدره ثلاثة أسابيع، وبلغت نسبة الاتفاق 9V٪، وبذلك تم التوصل إلى قائمة المفاهيم المتضمنة في وحدة "مظاهر الحضارة

$$
\text { ب- إعصرية القديمة" (ملحق ). }
$$

قام الباحث بإعداد دليل المعلم لتدريس وحدتي"شخصيات وأحداث من التاريخ الفرعوني،

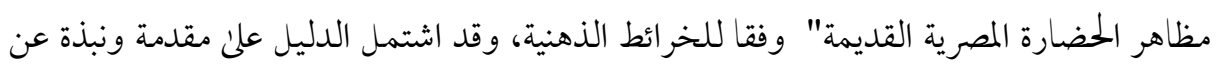
الخر ائط الذهنية والفلسفة التي تقوم عليها، وتوجيهات عامة للمعلم لتنفيذ الدروس وما يرتبط بها من أنشطة، وأهداف تدريس الوحدة والوسائل التعليمية، والتوزيع الزمني لموضوعات الوحدة، وقائمة بأهم المراجع العلمية لكل من المعلم والتلميذ، وخطة السير في تدريس الوحدة، وتشمل الأهداف

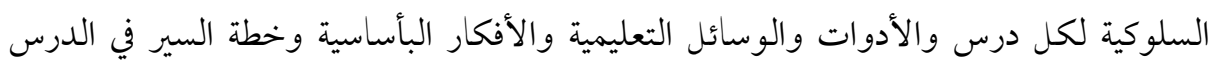




\section{ثالثا ـ إعداد أدوات الدراسة \\ - إعداد اختبار المفاهيم التاريخية}

أ- الهدف من الاختبار: هدف الاختبار إلى التعرف علن أثر تدريس وحدتي "شخصيات وأحداث من التاريخ الفرعوني، مظاهر الحضارة المصرية القديمة" وفقا لاستراتيجية الخر ائط الذهنية في تنمية المفاهيم التاريخية لدئ تلاميذ الصف الرابع الابتدائي. ب- أبعاد الاختبار: تم اتباع نموذج "وسكونسن" Wisconsinلتقويم تعلم المفاهيم، وقد صيغت مفردات الاختبار وفقا لنمط الاختيار من متعدد رباعي البدائل، وروعي مناسبة المفردات لمستوى تلاميذ الصف الرابع الابتدائي، كما روعي فيها الوضوح وسهولة الألفاظ.

ج- صدق الاختبار: تم عرض الاختبار في صورته الأولية علن بجموعة من الخبراء في بجال المناهج وطرق تدريس التاريخ وذلك للحكم علن مدئ ملاءمته لمستوئ التلاميذ، ومدئ الصحة العلمية لمفرداته، وتو افقها مع المستويات الدنيا والعليا، وكذلك مدىن وضوح

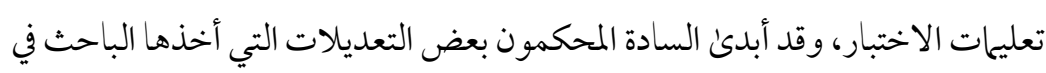
الاعتبار عند اعداد الصورة النهائية مثل: تجانس البدائل واختصارها.

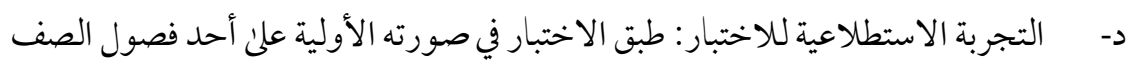
الرابع الابتدائي وعددهم بr تلميذا وهم من غير المجموعة الأصلية وذلك بغرض:

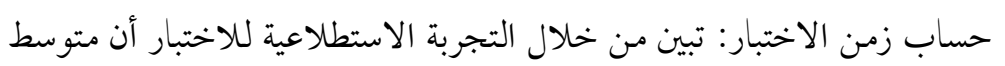
الزمن المناسب لانتهاء جميع التلاميذ من الاجابة علن مفرداته هو 0 ع دقيقة. حساب ثبات الاختبار : تم حساب ثبات الاختبار باستخدام طريقة التجزئة النصفية بمعادلة سبيرمان وبراون، وحيث إن معامل الارتباط بين نصفي المقياس بلغ rم ,، فإن معامل الثبات بلغ • 9 , وهو معامل مرتفع من الثبات ويمكن الوثوق به. 
Dr. Ibrahim Abdulfattah Rezq

Volume (3) No. (3) 2020

ه- الصورة النهائية للاختبار: بلغ عدد مفردات الاختبار في صورته النهائية • م مفردة، وقد أعطي لكل مفردة يجيب عنها التلميذ إجابة صحيحة درجة واحدة، وصفر للاجابة الخطأ، وبذلك تكون الدرجة النهائية للاختبار · س درجة، ويوضح جدول ا مواصفات

$$
\text { اختبار المفاهيم التاريخية. }
$$

جدول (1) مواصفات اختبار المفاهيم التاريخية وفقا لنموذج ويسكونسن Wisconsin

\begin{tabular}{|c|c|c|c|}
\hline المجموع & أرقام الأسئلة & أبعاد الاختبار وفق نموذج ويسكونسن & مستويات تعلم المفاهيم \\
\hline$r$ & 4161161 & ا ـ اعطاء اسم المفهوم ويختار التلميذ المثال الموجب & \multirow{2}{*}{ المستوئ الأدنى (التمييز بين الأمثلة } \\
\hline$r$ & YY,IYG & r _ اعطاء اسم المفهوم ويختار التلميذ المثال السالب & \\
\hline r & r r r r & بـ اعطاء المثال الموجب للمفهوم ويختار التلميذ & \multirow{8}{*}{ 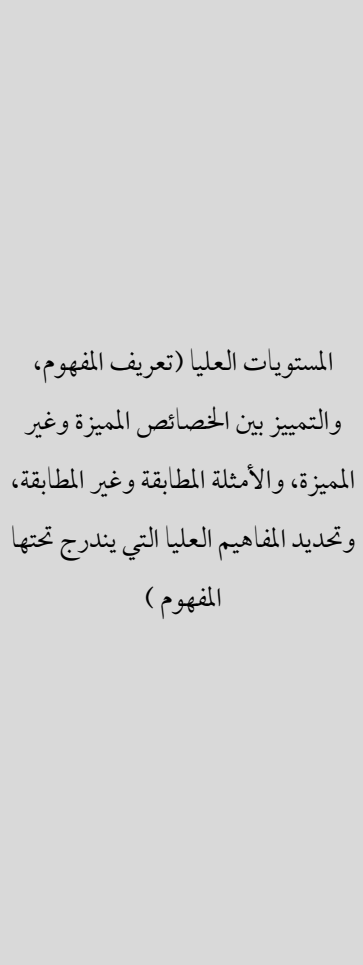 } \\
\hline$r$ & $r\{, 1\} ، \varepsilon$ & عـ اعطاء اسم المفهوم ويختار التلميذ الخاصية & \\
\hline$r$ & Yo, 10,0 & 0ـ اعطاء اسم المفهوم ويختار التلميذ الخاصية غير & \\
\hline$r$ & Y7.17.7 & 7ـ اعطاء معنى المفهوم، ويختار التلميذ اسم & \\
\hline$r$ & YV، IV ، V & V_ اعطاء اسم المفهوم، ويختار التلميذ معنى & \\
\hline$r$ & 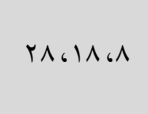 & ^ــ اعطاء اسم المفهوم ويختار التلميذ المفهوم & \\
\hline$r$ & 19.19 .9 & 9_ اعطاء اسم المفهوم ويختار التلميذ المفهوم & \\
\hline$r$ & $r \cdot 6 r \cdot 61 \cdot$ & • 1 ـ اعطاء اسم مفهومين، ويختار التلميذ المبدأ & \\
\hline & r. & وع · أبعاد & \\
\hline
\end{tabular}


r- - إعداد اختبار التفكير البصري

أ- الهدف من الاختبار:التعرف علئ أثر تدريس وحدتي "شخصيات وأحداث من التاريخ الفرعوني، مظاهر الحضارة المصرية القديمة" وفقا لاستراتيجية الخر ائط الذهنية في تنمية مهارات التفكير البصري لدئ تلاميذ الصف الرابع الابتدائي.

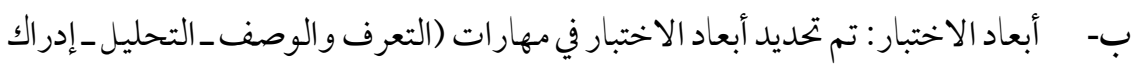


ويتبع كل خريطة أو شكل أو صورة عبارة ناقصة أو سؤال، وروعي مناسبة المفردات ووضوحها وسهولة ألفاظها لمستوى تلاميذ الصف الرابع الابتدائي. ج- صدق الاختبار: تم عرض الاختبار في صورته الأولية على المحكمين للحكم على مدئ دقة ووضوح الخرائط والأشكال والصور، والصحة العلمية للمفردات ومناسبتها

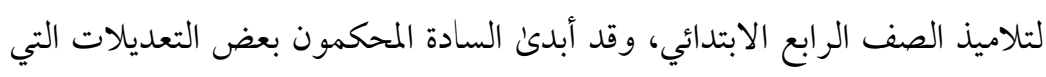
أخذها الباحث في الاعتبار عند اعداد الصورة النهائية، مثل تعديل بعض البدائل واختيار التيل

$$
\text { صور أكثر وضوحاوتمييزا. }
$$

د- التجربة الاستطلاعية للاختبار : طبق الاختبار في صورته الأولية على مجموعة من تلاميذ

$$
\text { الرابع الابتدائي غير عينة البحث وذلك بغرض: }
$$

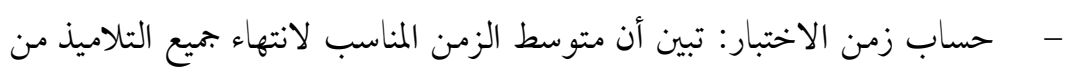

$$
\text { الاجابة على الاختبار هو 0ـ دقيقة. }
$$

- - مساب ثبات الاختبار: تم حساب ثبات الاختبار باستخدام طريقة التجزئة النصفية بمعادلة سبيرمان وبراون ووجد أنه يساوي (سب, • • (1) مما يدل علن أنه يتمتع بدرجة عالية من الثبات.

ه- الصورة النهائية للاختبار: بلغ عدد مفردات الاختبار في صورته النهائية ب مفردة وقد أعطي لكل مفردة يجيب عليها التلميذ اجابة صحيحة درجة واحدة وصفر للاجابة الخطأ، 
وبذلك تكون الدرجة النهائية للاختبار r Y درجة و الصغرئ صفر ويوضح (جدول r) مو اصفات اختبار التفكير البصري.

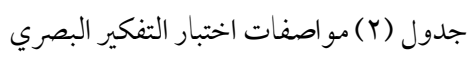

\begin{tabular}{|c|c|c|c|c|c|c|c|}
\hline \multirow{2}{*}{ ال النسبة } & \multirow[b]{2}{*}{ المجموع } & \multicolumn{5}{|c|}{ المهارة } & \multirow[b]{2}{*}{ الموضوع } \\
\hline & & ص المعنى & تفسير & العلاقات & ل التحلي & والتورف & \\
\hline$\%|\wedge, \wedge|$ & $\varepsilon$ & - & 1 & r & - & 1 & شخصيات وأحداث من \\
\hline$\% 9, \cdot 9$ & r & 1 & & - & 1 & - & شخصيات وأحداث من \\
\hline \%rr, Vr & 0 & - & r & 1 & 1 & 1 & شخصيات وأحداث من \\
\hline$\% 9, \cdot 9$ & r & r & - & - & - & - & نظام الحكم \\
\hline rT, & r & - & - & 1 & - & r & الحياة الدينية \\
\hline$\% \varepsilon, 0 \varepsilon$ & 1 & 1 & - & - & - & - & الحياة الاجتماعية \\
\hline$\% r r, v r$ & 。 & r & 1 & 1 & - & 1 & الحياة الاقتصادية \\
\hline$\% 1 \ldots$ & rY & 7 & $\varepsilon$ & 。 & r & 0 & المجموع \\
\hline
\end{tabular}

$$
\text { r- - ب - إعداد مقياس عادات العقل }
$$

أ- الهدف من المقياس: التعرف علن أثر تدريس وحدتي "شخصيات وأحداث من التاريخ الفرعوني، مظاهر الحضارة المصرية القديمة" وفقا لاستراتيجية الخر ائط الذهنية في تنمية

$$
\text { بعض عادات العقل لدئ تلاميذ الصف الرابع الابتدائي. }
$$

ب- أبعاد المقياس: تم تحديد أبعاد المقياس في عادات (المثابرة ـ الاصغاء بتفاهم وتعاطف ـ ـ التفكير بمرونة ـ التساؤل وطرح المشكلات) وقد صيغت مفردات المقياس في عدد من المو اقف تدل على أداء التلاميذ وممارستهم للعادات العقلية الأربعة السابقة، وقد راعئ 
الباحث أن يعبر كل موقف عن عادة عقلية واحدة، وقد درجت درجة الاجابة عن مو اقف المقياس تدرييا ثلاثيا كما روعي وضع تعليهات المقياس بصورة واضحة.

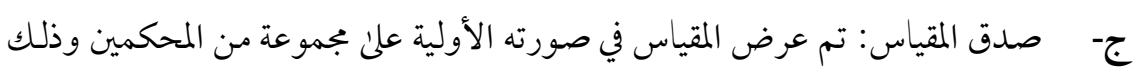
للحكم علن مدىن تمثيل المو اقف للعادات التي يقيسها المقياس، وقد أبدى المحكمون بعض الملاحظات التي أخذها الباحث في الاعتبار عند اعداد الصورة النهائية، مثل تعديل بعض المواقف، واستبعاد بعضها. د- التجربة الاستطلاعية للمقياس: طبق المقياس في صورته الأولية علن بجموعة من التلاميذ غير عينة البحث وذلك بغرض ه- حساب زمن المقياس: تبين أن متوسط الزمن المناسب لانتهاء جميع التلاميذ من الاجابة علن عبار ات المقياس هو • ع دقيقة. و- حساب ثبات المقياس: تم حساب ثبات المقياس باستخدام معادلة ألفا كرونباخ، ووجد أن معامل الثبات 1 , ، · مما يدل علن أنه يتمتع بدرجة عالية من الثبات. ز- الصورة النهائية للمقياس: بلغ عدد مو اقف المقياس في صورته النهائية 17 موقف. وبذلك تكون الدرجة العظمى للمقياس ^ع درجة، والدرجة الصغرى 17 درجة، ويوضح

$$
\text { جدول بم مو اصفات مقياس عادات العقل. }
$$

جدول (r) مو اصفات مقياس عادات العقل

\begin{tabular}{|c|c|c|c|}
\hline المجموع & المواقف & العادات العقلية & p \\
\hline$\varepsilon$ & $1 r 6960,1$ & المثابرة & 1 \\
\hline$\varepsilon$ & $1 \varepsilon, 1 \cdot$ ، T, & الاصغاء بتفاهم وتعاطف & r \\
\hline$\varepsilon$ & $10,11 ، \mathrm{~V}, \mathrm{r}$ & التفكير بمرونة & r \\
\hline$\varepsilon$ & 17، & التساؤل وطرح المشكلات & $\varepsilon$ \\
\hline 17 & \multicolumn{3}{|c|}{ المجموع } \\
\hline
\end{tabular}




$$
\text { رابعا ـ التصميم التجريبي واجر اءات التجربة }
$$

1- منهج البحث: استخدم البحث المنهج شبه التجريبي القائم على تصميم المعالجات التجريبية

$$
\text { القبلية والبعدية من خلال المجموعتين التاليتين: }
$$

المجموعة التجريبية: وتضم بجموعة من تلاميذ الصف الرابع الابتدائي يدرسون وحدتي

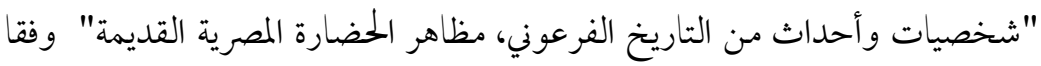

$$
\text { لاستراتيجية الخرائط الذهنية. }
$$

المجموعة الضابطة: وتضم مجموعة تلاميذ الصف الرابع الابتدائي الذين يدرسون

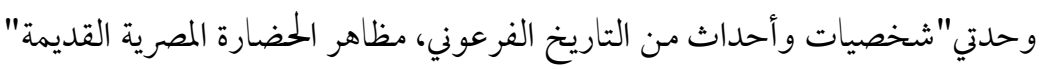

$$
\text { بالطريقة المعتادة. }
$$

r- متغيرات البحث: اشتمل التصميم التجريبي على المتغيرات التالية:

• متغيرات مستقلة: - التدريس باستخدام الخر ائط الذهنية.

$$
\begin{aligned}
& \text { - التدريس بالطريقة المعتادة. } \\
& \text { • متغيرات تابعة: }
\end{aligned}
$$

\begin{tabular}{|c|c|c|}
\hline العدد & الفصل & المجحموعة \\
\hline$r$. & $1 / \varepsilon$ & التجريبية \\
\hline$r$. & $r / \varepsilon$ & الضابطة \\
\hline
\end{tabular}

$$
\text { - - - - المفاهيم التاريخية: وتقاس باستخدام اختبار المفاهيم التاريخية. }
$$

ץ- عينة البحث: تم اختيار عينة البحث من مدرسة التعليم الأساسي ببشتامي بإدارة الشهداء التعليمية بمحافظة المنوفية هما فصلي ع / ا، ع/ ع ويوضح جدول (ع) مواصفات عينة

$$
\text { البحث }
$$

$$
\text { جدول (ع) مو اصفات عينة البحث }
$$


ع - التطبيق القبلي لأدوات البحث: تم تطبيق أدوات البحث علن كل من المجموعتين التجريبية و الضابطة للتأكد من تكافؤ المجموعتين، والحصول على المعلومات القبلية التي تساعد في العمليات الاحصائية الخاصة بنتائج البحث، ويوضح جدول (0) نتائج التطبيق القبلي:

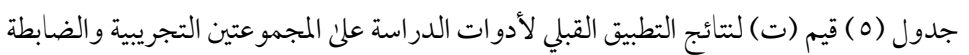

\begin{tabular}{|c|c|c|c|c|c|c|}
\hline \multirow{2}{*}{ مستوى الدلالة } & \multirow{2}{*}{ قيمة ت } & \multicolumn{2}{|c|}{ المجموعة الضابطة } & \multicolumn{2}{|c|}{ المجموعة التجريبية } & \multirow{2}{*}{ نوع الاختبار } \\
\hline & & $r_{\varepsilon}$ & $r_{p}$ & $1 \varepsilon$ & ip & \\
\hline 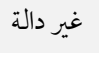 & $\cdot, r)$ & r, 07 & $\varepsilon, \wedge$. & $r, 70$ & $\varepsilon, 7$ & المفاهيم التاريخية \\
\hline غير دالة ل & $\cdot, r Y$ & 1,10 & 1,97 & $1, \cdot 9$ & $1,9$. & التفكير البصري \\
\hline 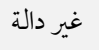 & $\cdot, \cdot \wedge$ & $\varepsilon, \vee\urcorner$ & $r r, i r$ & $\varepsilon, \uparrow$ & $r, r, r$ & عادات العقل \\
\hline
\end{tabular}

يتبين من جدول (0) أن الفروق بين متوسطات درجات كل من المجموعتين التجريبية و الضابطة علن اختبار المفاهيم التاريخية، واختبار التفكير البصري، ومقياس عادات العقل غير دالة، مما يعني أنه لا توجد فروق ذات دلالة احصائية بين المجموعتين التجريبية والضابطة قبليا، وهذا يدل علئ تكافؤ المجموعتين.

$$
\text { 0- - تدريس الوحدة }
$$

قبل اجراء التجربة التقى الباحث بمعلم الدراسات الاجتماعية لفصل المجموعة التجريبة؛ لتوضيح الغرض من الدراسة، و أهميتها، واجراءات التدريس باستخدام الخر ائط الذهنية، ودور كل من لن المعلم والتلميذ أثناء عملية التعلم، مع مراعاة تقسيم التلاميذ إلى مجموعات تعاونية، وتشجيعهم علن اجراء الأشطة وأوراق العمل، وتسجيل ملاحظاتهم استناجاتهم، مع تزويد المعلم بدليل المعلم للاسترشاد به في عملية التدريس، وقد قام المعلم بالتدريس مع المتابعة المستمرة من الباحث، وقبل تدريس الوحدة تم تخصيص حصة لتعريف التلاميذ بالخرائط الذهنية، وأهميتها، والهدف من استخدامها، وخطو ات رسمها وبناءها، وتم عرض نموذج لدرس من دروس الوحدة، أما بالنسبة لمعلم الجموعة الضابطة فقد قام بالتدريس وفقا للطريقة المعتادة. 


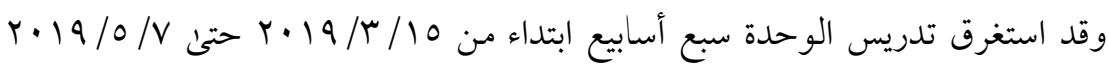
وروعي أن تكون المدة متساوية للمجموعتين التجريبية والضابطة. r- التطبيق البعدي لأدوات البحث: بعد الانتهاء من تدريس الوحدة لكل من المجموعتين

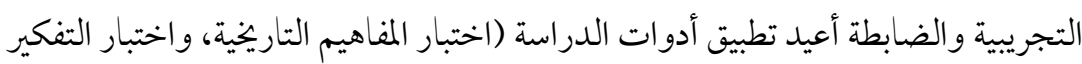
البصري، ومقياس عادات العقل) وقد تم التصحيح وتحليل البيانات احصائيا. خامسا: عرض النتائج ومناقشتها وتفسيرها: فيما يلي عرض لأهم النتائج التي تم التوصل إليها، للاجابة على أسئلة البحث و التحقق من صحة فروضها. 1- النتائج الخاصة باختبار المفاهيم العلمية اختبار صحة الفرض الأول: ينص الفرض الأول للدراسة على أنه "توجد فروق ذات دلالة احصائية بين متوسطات درجات تلاميذ المجموعتين التجريبية والضابطة في التطبيق البعدي لاختبار المفاهيم التاريخية ومستوياته المختلفة لصالح تلاميذ المجموعة التجريبية". ولاختبار صحة هذا الفرض تم حساب المتوسطات والانحرافات المعيارية وقيم (ت) لدرجات تلاميذ المجموعتين التجريبية والضابطة في التطبيق البعدي لاختبار المفاهيم التاريخية ومستوياته المختلفة وجدول (7) يوضح ذلك. جدول (7) المتوسطات والانحر افات المعيارية وقيم (ت) وحجم التأثير لنتائج التطبيق البعدي لاختبار المفاهيم التاريخية علن كل من الجموعتين التجريبية والضابطة

\begin{tabular}{|c|c|c|c|c|c|c|c|c|}
\hline \multirow{2}{*}{ التأثير } & \multirow{2}{*}{ مستوى الدلالة } & \multirow{2}{*}{ قيمة ت } & \multicolumn{2}{|c|}{ المجموعة الضابطة } & \multicolumn{2}{|c|}{ المجموعة التجريبية } & \multirow{2}{*}{\multicolumn{2}{|c|}{ مستويات }} \\
\hline & & & $r_{\varepsilon}$ & $r_{p}$ & $1 \varepsilon$ & ip & & \\
\hline$r, q 7$ & دالة عند مستوىن & $1 \cdot, \mathrm{TV}$ & זו, • & $r, \cdot r$ & $\cdot, r_{0}$ & $r, q r$ & 1 & المستوى \\
\hline$r, \uparrow$ & دالة عند مستوىن & $V, r r$ & $\cdot$, • & $r, \cdot r$ & $\cdot, \varepsilon \cdot$ & $r, \wedge$. & r & الأدنى \\
\hline$r, \xi$. & دالة عند مستون & $\curlyvee,\{\wedge$ & $\cdot, \varepsilon \varepsilon$ & 1,95 & $\cdot, \Sigma\rceil$ & $r, v$. & $r$ & المستويات \\
\hline
\end{tabular}




\begin{tabular}{|c|c|c|c|c|c|c|c|c|}
\hline \multirow{2}{*}{ حجم التأثير } & \multirow{2}{*}{ مستوى الدلالة } & \multirow{2}{*}{ قيمةت } & \multicolumn{2}{|c|}{ المجموعة الضابطة } & \multicolumn{2}{|c|}{ المجموعة التجريبية } & \multirow{2}{*}{\multicolumn{2}{|c|}{ الاختبار }} \\
\hline & & & $r_{\varepsilon}$ & $r_{p}$ & $1 \varepsilon$ & Ip & & \\
\hline$r, 01$ & دالة عند مستوى' & $\mathrm{T}, \mathrm{VV}$ & $\cdot, \varepsilon r$ & 1,17 & $\cdot, \varepsilon V$ & $r, T T$ & $\varepsilon$ & \\
\hline r r r & دالة عند مستوىن & $T, r V$ & $\cdot, 00$ & 1, & $\cdot$, ro & $r, \cdot T$ & 0 & \\
\hline rr, r & دالة عند مستوىن & T, YV & $\cdot, 7$. & r וr, & $\cdot, r \varepsilon$ & $r, i r$ & 7 & \\
\hline$r, r v$ & دالة عند مستوني & $9, \cdot 1$ & $\cdot, 0\}$ & ת & $\cdot, 0$. & $r, 07$ & $v$ & \\
\hline 1,09 & دالة عند مستوىن & $\varepsilon, r \cdot$ & r & $1, v r$ & $\cdot,\{१$ & $r, r r$ & $\wedge$ & \\
\hline $1, \varepsilon \wedge$ & دالة عند مستوىن & $\varepsilon$ & $\cdot$, or & r & $\cdot, 0$. & r,or & 9 & \\
\hline$r, \varepsilon r$ & دالة عند مستوى & 7,07 & $\cdot, \varepsilon १$ & $1, \varepsilon$. & $\cdot, r \cdot$ & $r, 1$. & 1. & \\
\hline$r, v i$ & دالة عند مستوى & 9,91 & $r, 0$. & $1 \mathrm{~V}, \cdot \mathrm{T}$ & $Y, \leqslant 0$ & $r \varepsilon, \wedge \tau$ & & الكلي \\
\hline
\end{tabular}

يتضح من جدول (7) وجود فروق ذات دلالة احصائية بين متوسطات درجات المجموعتين التجريبية و الضابطة في التطبيق البعدي لاختبار المفاهيم التاريخية ومستوياته المختلفة لصالح المجموعة التجريبية، وبذلك يقبل الفرض الأول للدراسة، كما يتضح أن حجم تأثير استخدام الخرائط الذهنية على المفاهيم التاريخية لتلاميذ المجموعة التجريبية كبير جيث أن حجم التأثير يكون كبير إذا كانت قيمته أكبر من بن $\cdot, \wedge$ اختبار صحة الفرض الثاني: ينص الفرض الثاني للدراسة على أنه "توجد فروق ذات دلالة احصائية بين متوسطات درجات تلاميذ المجموعة التجريبية في التطبيق البعدي والتطبيق القبلي لاختبار المفاهيم التاريخية ومستوياته المختلفة لصالح التطبيق البعدي". 
Dr. Ibrahim Abdulfattah Rezq

Volume (3) No. (3) 2020

ولاختبار صحة هذا الفرض تم حساب المتوسطات والانحرافات المعيارية وقيم (ت) لدرجات تلاميذ المجموعة التجريبية في التطبيق القبلي والبعدي لاختبار المفاهيم التاريخية ومستوياته المختلفة وجدول (V) يوضح ذلك. جدول (V) المتوسطات والانحر افات المعيارية وقيم (ت) وحجم التأثير لنتائج التطبيق القبلي والبعدي لاختبار المفاهيم التاريخية علن الجموعة التجريبية

\begin{tabular}{|c|c|c|c|c|c|c|c|c|}
\hline حجم & \multirow{2}{*}{ دلالة قيمة ت } & \multirow{2}{*}{ قيمة ت } & \multicolumn{2}{|c|}{ التطبيق البعدي } & \multicolumn{2}{|c|}{ التطبيق القبلي } & \multirow{2}{*}{\multicolumn{2}{|c|}{ مستويات الاختبار }} \\
\hline التأثير & & & $r_{\varepsilon}$ & $r_{p}$ & $1 \varepsilon$ & lp & & \\
\hline $1 \cdot, \cdot \varepsilon$ & دالة عند مستوئ 1 • , . & $r V, \cdot r$ & $\cdot$, ro & $r, q r$ & $\cdot, \varepsilon q$ & ש & 1 & المستوى \\
\hline 7,77 & دالة عند مستوى 1 • , . & $1 V, q \varepsilon$ & $\cdot, \xi \cdot$ & $r, \wedge \cdot$ & $\cdot, 0$. & $\cdot, 0$. & r & الأدنى \\
\hline T, rV & دالة عند مستوئ 1 • , . & $|V,| \varepsilon$ & $\cdot, \varepsilon\rceil$ & $r, v \cdot$ & $\cdot, 0$. & $\cdot, 07$ & $r$ & \\
\hline $7, Y T$ & دالة عند مستوئ 1 . , . & 17,17 & $\cdot, \varepsilon V$ & $r, r T$ & $\cdot, 0$. & $\cdot,\{7$ & $\varepsilon$ & \\
\hline $0, r \mu$ & دالة عند مستوي ا • , . & $1 \varepsilon, \cdot \wedge$ & $\cdot, 0$. & $r, o r$ & $\cdot, 0$. & $\cdot, 07$ & $\circ$ & \\
\hline T, rY & دالة عند مستوى 1 • , . & $I V, \cdot r$ & $\cdot, \imath १$ & $r, r r$ & $\cdot, \varepsilon q$ & $\cdot, r$ r & 7 & المستويات \\
\hline$V, Y_{I}$ & دالة عند مستوئ 1 • , . & $19, \varepsilon$. & $\cdot, 0$. & $r, 07$ & $\cdot, 0$. & $\cdot, 0$. & $\checkmark$ & العليا \\
\hline 7,70 & دالة عند مستوئ 1 . , . & $1 V, \wedge 9$ & $\cdot, r \varepsilon$ & $r, i r$ & $\cdot, \varepsilon \vee$ & r & $\wedge$ & \\
\hline $0,9 V$ & دالة عند مستوئ 1 • , • & $17, \cdot 1$ & $\cdot$, ro & $r, \cdot r$ & $\cdot, 0$. & $\cdot, \varepsilon r$ & 9 & \\
\hline$v, \cdot r$ & دالة عند مستوى 1 • , . & $1 \wedge, 9 Y$ & $\cdot, r \cdot$ & $r, 1$ & $\cdot, \varepsilon \varepsilon$ & $\cdot, \pi$ & 1. & \\
\hline $11, \wedge 7$ & دالة عند مستوى 1 ـ , · & r I, ar & $r, \varsigma_{0}$ & $r \varepsilon, \wedge T$ & r, rr & זו & & الكلي \\
\hline
\end{tabular}

يتضح من جدول (V) وجود فروق ذات دلالة احصائية بين متوسطات درجات المجموعة التجريبية في التطبيق القبلي والبعدي لاختبار المفاهيم التاريخية ومستوياته المختلفة لصالح التطبيق البعدي، وبذلك يقبل الفرض الثاني للدراسة، كما يتضح أن حجم التأثير كبير مما يدل علن أن تأثير استخدام الخرائط الذهنية في تنمية المفاهيم التاريخية لدىن تلاميذ المجموعة التجريبية كبير. r - النتائج الخاصة باختبار التفكير البصري 
اختبار صحة الفرض الثالث: ينص الفرض الثالث للدراسة علن أنه "توجد فروق ذات دلالة احصائية بين متوسطات درجات تلاميذ المجموعتين التجريبية والضابطة في التطبيق البعدي لاختبار التفكير البصري ومهار اته المختلفة لصالح تلاميذ المجموعة التجريبية". ولاختبار صحة هذا الفرض تم حساب المتوسطات والانحرافات المعيارية وقيم (ت) لدرجات تلاميذ المجموعتين التجريبية والضابطة في التطبيق البعدي لاختبار التفكير البصري ومهاراته المختلفة وجدول (^) يوضح ذلك. جدول (^) المتوسطات والاتنحرافات المعيارية وقيم (ت) وحجم التأثير لنتائج التطبيق البعدي لاختبار التفكير البصري علن كل من الجموعتين التجريبية والضابطة

\begin{tabular}{|c|c|c|c|c|c|c|c|}
\hline \multirow{2}{*}{ التأثير } & \multirow{2}{*}{ ودلالة قيمة ت } & \multirow{2}{*}{ قيمة ت } & \multicolumn{2}{|c|}{ المجموعة الضابطة } & \multicolumn{2}{|c|}{ المجموعة التجريبية } & \multirow{2}{*}{ الاختبار } \\
\hline & & & $r_{\varepsilon}$ & $r_{\rho}$ & $1 \varepsilon$ & Ip & \\
\hline$r, \bullet \wedge$ & دالة عند ا • , • & 5.62 & 0.67 & 3.60 & 0.50 & 4.46 & والتعرف \\
\hline $1, v r$ & دالة عند ا • , · & 4.64 & 0.47 & 0.66 & 0.40 & 0.20 & التحليل \\
\hline$\varepsilon, 77$ & دالة عند ا • , · & 12.56 & 0.74 & 2.16 & 0.50 & 4.23 & العلاقات \\
\hline$r, v \varepsilon$ & دالة عند ا • , · & 10.08 & 0.52 & 1.73 & 0.71 & 3.36 & التفسير \\
\hline 7 & دالة عند ا • , · & 16.15 & 0.45 & 2 & 0.54 & 4.10 & استخلاص \\
\hline $0, r r$ & دالة عند ا • , . & 14.32 & 1.80 & 10.20 & 2.05 & 17.36 & الاختبار الكلي \\
\hline
\end{tabular}

يتضح من جدول (^) وجود فروق ذات دلالة احصائية بين متوسطات درجات المجموعتين التجريبة والضابطة في التطبيق البعدي لاختبار التفكير البصري ومهاراته المختلفة لصالح المجموعة التجريبة، وبذلك يقبل الفرض الثالث للدراسة، كما يتضح أن حجم تأثير استخدام الخر ائط الذهنية في تنمية التفكير البصري لدئ تلاميذ المجموعة التجريبية كبير. 
اختبار صحة الفرض الرابع: ينص الفرض الرابع للدراسة علن أنه "توجد فروق ذات دلالة احصائية بين متوسطات درجات تلاميذ المجموعة التجريبية في التطبيق القبلي والبعدي لاختبار التفكير البصري ومهار اته المختلفة لصالح التطبيق البعدي". ولاختبار صحة هذا الفرض تم حساب المتوسطات والانحرافات المعيارية وقيم (ت) لدرجات تلاميذ المجموعتين التجريبية في التطبيق القبلي والبعدي لاختبار التفكير البصري ومهاراته المختلفة وجدول (9) يوضح ذلك. جدول (9) المتو سطات والاتنحرافات المعيارية وقيم (ت) وحجم التأثير لنتائج التطبيق القبلي والبعدي لاختبار التفكير البصري علن الجموعة التجريبية

\begin{tabular}{|c|c|c|c|c|c|c|c|}
\hline \multirow{2}{*}{ حجم التأثير } & \multirow{2}{*}{ دلالة قيمة ت } & \multirow{2}{*}{ قيمة ت } & \multicolumn{2}{|c|}{ التطبيق القبلي } & \multicolumn{2}{|c|}{ التطبيق البعدي } & \multirow{2}{*}{ مهارات } \\
\hline & & & $r_{\varepsilon}$ & $r_{\rho}$ & $1 \varepsilon$ & lp & \\
\hline$|r, \varepsilon|$ & دالة عند ا • , · & 33.39 & 0.68 & 1.13 & 0.50 & 4.46 & والتعرف \\
\hline $0,1 \varepsilon$ & دالة عند ا • , • & 13.85 & 0.18 & 0.03 & 0.40 & 1.20 & التحليل \\
\hline $1 \Gamma, \wedge 7$ & دالة عند ا • , . & 37.31 & 0.43 & 0.23 & 0.50 & 4.23 & العلاقات \\
\hline$\wedge, 1 \varepsilon$ & دالة عند ا · , · & 21.91 & 0.40 & 0.20 & 0.71 & 3.36 & التفسير \\
\hline$I Y, T V$ & دالة عند ا • , . & 34.10 & 0.46 & 0.30 & 0.54 & 4.10 & استخلاص المعنى \\
\hline$r \varepsilon, 7 I$ & دالة عند ا • , . & 66.21 & 1.09 & 1.90 & 2.05 & 17.36 & الاختبار الكلي \\
\hline
\end{tabular}

يتضح من جدول (9) وجود فروق ذات دلالة احصائية بين متوسطات درجات المجموعة التجريبية في التطبيق القبلي والبعدي لاختبار التفكير البصري ومهاراته المختلفة لصالح التطبيق البعدي، وبذلك يقبل الفرض الرابع للدراسة، كما يتضح أن حجم التأثير كبير مما يدل علن تأثير استخدام الخر ائط الذهنية في تنمية التفكير البصري لدئ تلاميذ المجموعة التجريبية. 


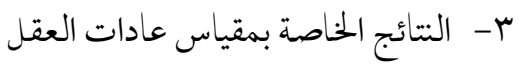

اختبار صحة الفرض الخامس: ينص الفرض الخامس للدراسة على أنه "توجد فروق ذات

دلالة احصائية بين متوسطات درجات تلاميذ المجموعتين التجريبية والضابطة في التطبيق البعدي لمقياس عادات العقل ومهاراته المختلفة لصالح تلاميذ المجموعة التجريبية"، ولاختبار صحة هذا الفرض تم حساب المتوسطات والانحرافات المعيارية وقيم (ت) لدرجات تلاميذ المجموعتين التجريبة والضابطة في التطبيق البعدي لاختبار التفكير البصري ومهاراته المختلفة وجدول (•) يوضح ذلك. جدول (• () المتوسطات والاتنحر افات المعيارية وقيم (ت) وحجم التأثير لنتائج التطبيق البعدي لمقياس عادات العقل علن الجموعتين التجريبية والضابطة

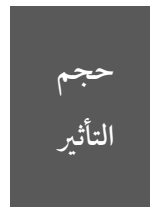

$r, 9$.

دالة عند ا •, •

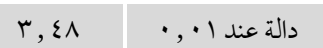

\begin{tabular}{l|l|l|}
\hline & & 8.88
\end{tabular}

\begin{tabular}{|c|c|}
\hline , & دالة عند ا • , • \\
\hline
\end{tabular}

r, 10.33

7.82

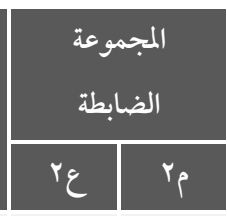

1.22

1.23

1.71

1.43

1.43

4.76

7.26

4.30

6.50

24.10

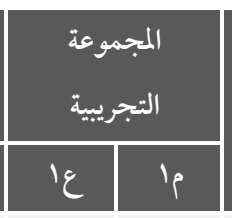

\begin{tabular}{l|l}
6.03 & 1.44 \\
\hline
\end{tabular}
1.49

1.62

10.03

7.80

الإصغاء بتفهم وتعاطف

1.45

1.45

5.16

9.86

المثابرة

37.36

المقياس ككل

يتضح من جدول ( • () وجود فروق ذات دلالة احصائية بين متوسطات درجات المجموعتين التجريبية والضابطة في التطبيق البعدي لمقياس عادات العقل ومهاراته المختلفة لصالح المجموعة التجريبة، وبذلك يقبل الفرض الخامس للدراسة، كما يتضح أن حجم تأثير استخدام الخرائط الذهنية في تنمية عادات العقل لدى تلاميذ المجموعة التجريبية كبير. اختبار صحة الفرض السادس: ينص الفرض السادس للدراسة علن أنه "توجد فروق ذات دلالة احصائية بين متوسطات درجات تلاميذ المجموعة التجريبية في التطبيق القبلي والبعدي لمقياس

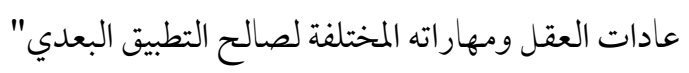


ولاختبار صحة هذا الفرض تم حساب المتوسطات والانحرافات المعيارية وقيم (ت) لدرجات تلاميذ المجموعتين التجريبية في التطبيق القبلي والبعدي لمقياس عادات العقل ومهاراته المختلفة وجدول (9) يوضح ذلك. جدول (11) المتوسطات والاتنحر افات المعيارية وقيم (ت) وحجم التأثير لنتائج التطبيق القبلي والبعدي لمقياس عادات العقل علن الجموعة التجريية

\begin{tabular}{|c|c|c|c|c|c|c|c|}
\hline \multirow{2}{*}{ حجم التأثير } & \multirow{2}{*}{ دلالة قيمة ت } & \multirow{2}{*}{ قيمة ت } & \multicolumn{2}{|c|}{ التطبيق البعدي } & \multicolumn{2}{|c|}{ التطبيق القبلي } & \multirow{2}{*}{ العادات العقلية } \\
\hline & & & $r_{\varepsilon}$ & $r_{p}$ & $1 \varepsilon$ & ip & \\
\hline$r, r \varepsilon$ & دالة عند ا · , • & IV, $\cdot 7$ & $1, \varepsilon 9$ & $\begin{array}{c}1 \cdot, \cdot \\
r\end{array}$ & 1,11 & T, 4T & المساؤل وطرح \\
\hline $7, \cdot 0$ & دالة عند ا • , . & $17, Y 9$ & $1, \pi$ & $\vee, \wedge$. & $1,1 r$ & $r, 97$ & التفكير بمرونة \\
\hline $0, \cdot 1$ & دالة عند ا · , • & $1 r, \varepsilon q$ & $1, \varepsilon \varepsilon$ & 9,74 & 1,97 & $0, v r$ & الإصغاء بتفهم \\
\hline$\uparrow, r \varepsilon$ & دالة عند ا • , · & $\mathrm{IV}, \cdot \mathrm{A}$ & $1, \varepsilon 0$ & $9, \wedge 7$ & $1,0 r$ & $0, \varepsilon$. & المثابرة \\
\hline$\wedge, \wedge$. & دالة عند ا · , . & $r \mu,{ }_{r}$ & 0,17 & $\begin{array}{c}r v, r \\
r\end{array}$ & $\varepsilon, \uparrow$ & $r r, \cdot r$ & المقياس ككل \\
\hline
\end{tabular}
• أثبتت النتائج الخاصة باختبار المفاهيم التاريخية علن كل من المجموعتين التجريبية والضابطة بعديا، وعلن المجموعة التجريبية قبليا وبعديا أن هناك فروقا ذات دلالة إحصائية لصالح المجموعة التجريبية، ولصالح التطبيق البعدي. ويمكن إرجاع ذلك إلى أن استخدام الخرائط الذهنية في تدريس الوحدة ـــأتاح للتلاميذ الفرصة لتنظيم وتنسيق المعلومات والأفكار من خلال تحديد المفاهيم والأفكار الرئيسة والفرعية، وزاد من قدرتهم علن استيعاب المفاهيم، كما أن استخدام الصور والألوان في الخر ائط التي قاموا برسمها واعدادها، ساعد في تحسن فهمهم للمفاهيم وزاد من قدرتهم علنى استيعابها، بالإضافة إلى مناقشة المعلم 
لتلاميذه في الخرائط التي قاموا برسمها وبنائها وتقديم التغذية الراجعة لهم أدئ إلى المعالجة العميقة للمفاهيم.

وتتفق هذه النتائج مع نتائج بعض الدراسات منها: دراسة (Baggett, 2009) التي أوضحت

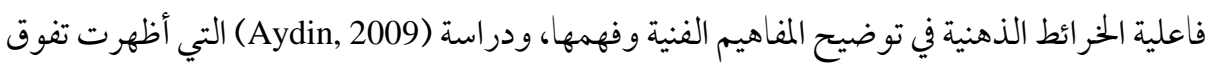

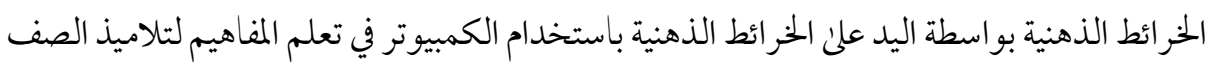
السادس الابتدائي، ودراسة (Harkirat, et al., 2010) التي أوضحت أن استخدام الخرائط الذهنية

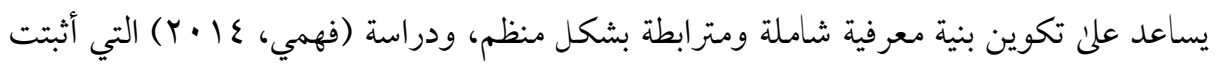
وجود فروق دالة احصائيا لاستخدام خرائط العقل في تنمية المفاهيم العلمية.

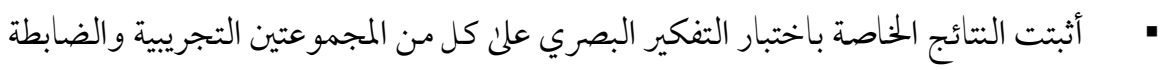

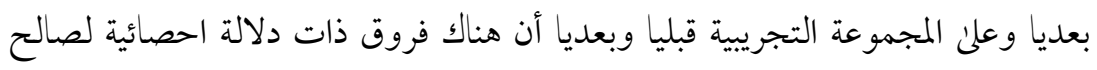
المجموعة التجريبية ولصالح التطبيق البعدي.

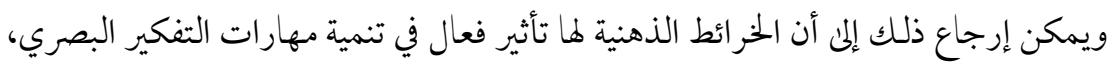

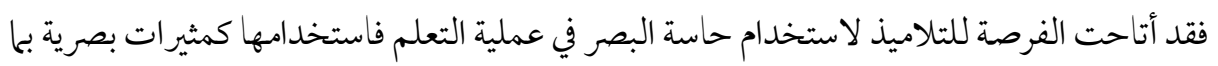

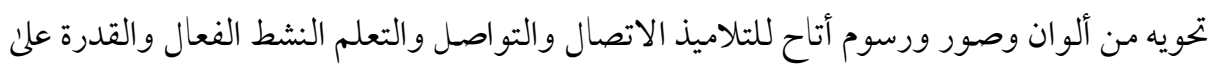
التخيل وإدراك العلاقات بين المفاهيم، وفهم طبيعة هذه العلاقات، كما ساعد التلاميذ علن المعالجة المهاح

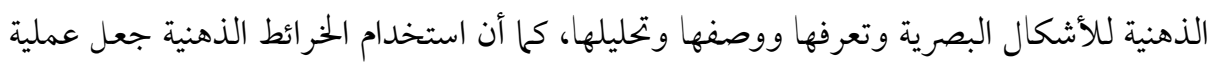
التدريس جذابة ومثيرة للاهتمام وأثار الدافعية لدئ التلاميذ، وشجعهم علن توظيف المعرفة بطريقة

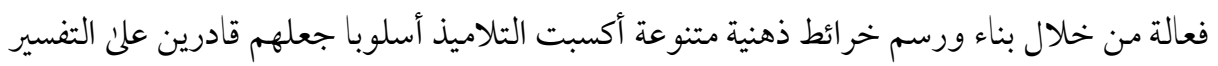

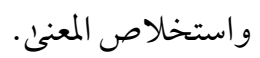

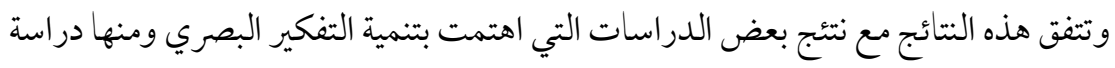

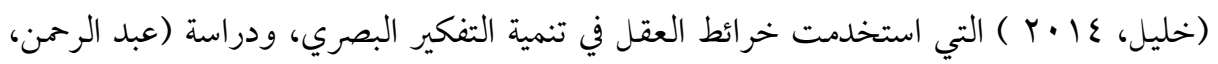

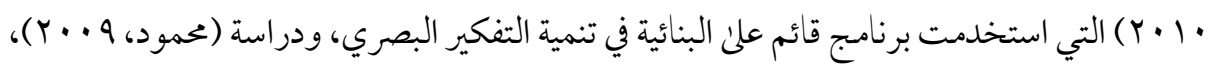




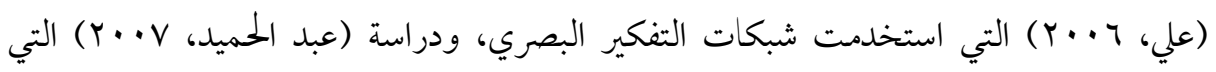
استخدمت الرسوم التوضيحية في تنمية التفكير البصري.

أثبتت النتائج الخاصة بمقياس عادات العقل علن كل من المجموعتين التجريبية والضابطة بعديا وعلن المجموعة التجريبية قبليا وبعديا أن هنالك فروق ذات دلالة إحصائية لصالح

$$
\text { المجموعة التجريبية ولصالح التطبيق البعدي. }
$$

ويمكن ارجاع ذلك إلى أن استخدام الخر ائط الذهنية في تدريس وحدتي "شخصيات وأحداث

من التاريخ الفرعوني، مظاهر الحضارة المصرية القديمة" ساعد التلاميذ علان ممارسة مهارات التخطيط و التنظيم والتقييم من خلال التخطيط لرسم الخرائط وتنظيم الأفكار والمفاهيم الرئيسة والفرعية، وتقييم أعمالهم من خلال التغذية الراجعة التي يقدمها لهم المعلم، كذلك ساعدت التلاميذ على القيام بدور إيبابي في توجيه وتنظيم عملية تعلمهم وتحمل مسئولية عملية التعلم، كذلك فإن قيام التلاميذ بالأشطة في مجموعات تعاونية أتاح الفرصة للمناقشة وتبادل الأفكار بين التلاميذ بعضهم البعض وبينهم وبين المعلم مما ساعد علئ تنمية بعض عادات العقل. وتتفق هذه النتائج مع نتائج بعض الدراسات التي اهتمت بتنمية عادات العقل منها دراسة

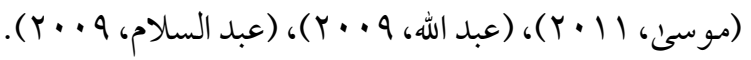

$$
\begin{aligned}
& \text { سادسا: التوصيات والمقترحات }
\end{aligned}
$$

في ضوء ما توصلت إليه الدراسة من نتائج، يمكن تقديم التوصيات والمقترحات التالية: ا. عقد دورات تدريبية لمعلمي وموجهي الدراسات الاجتماعية بالمرحلة الابتدائية لتدريبهم على

$$
\text { كيفية استخدام الخرائط الذهنية في تدريس التاريخ. }
$$

r. تضمين كتب الدراسات الاجتماعية بعض نماذج للخرائط الذهنية بها يتلاءم مع المحتون

$$
\text { الدراسي. }
$$

r. توجيه نظر القائمين على تطوير المناهج بإعادة النظر في تخطيط وتنظيم محتوى كتب الدراسات الاجتماعية في المرحلة الابتدائية؛ لتضمينها أنشطة ومهام تعليمية لتنمية عادات العقل. 
ع. الاهتمام بتضمين محتوكن مناهج الدراسات الاجتماعية بالمرحلة أنشطة بصرية يارسها التلاميذ

$$
\text { لتنمية مهارات التفكير البصري. }
$$

ه.إعداد أدلة لمعلم الدراسات الاجتماعية بالمر حلة؛ للمساعدة في تدريس الدراسات الاجتماعية

$$
\text { باستخدام الخر ائط الذهنية. }
$$

7. دراسة فاعلية بعض طرق واستراتيجيات التدريس الأخرى في تنمية التفكير البصري

$$
\text { وعادات العقل لدئ تلاميذ المرحلة. }
$$

V. دراسة أثر الخرائط الذهنية علن متغيرات أخرى مثل: مهارات حل المشكلات، والذكاء

$$
\text { الوجداني لدئ تلاميذ المرحلة. }
$$

^. دراسة أثر الخر ائط الذهنية في تنمية المفاهيم التاريخية والعادات العقلية لدئ طلاب المرحلتين

$$
\text { الاعدادية والثانوية. }
$$

9 . دراسة أثر استخدام الخرائط الذهنية في تنمية دافعية الانجاز والتفكير التوليدي لدىن تلاميذ المرحلة. 
ا. إبراهيم، خيري (1997): المواد الاجتمعية في مناهج التعليم بين النظرية والتطبيق، الإسكندرية، دار المعرفة الجامعية.

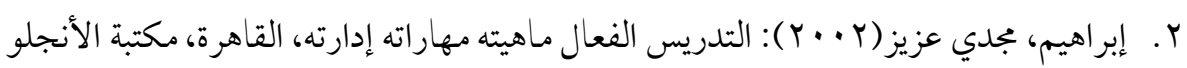
المصرية. - إيمات

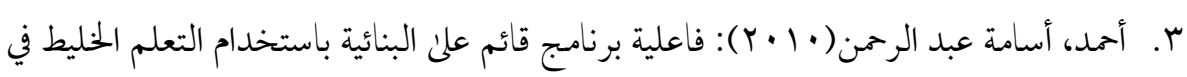



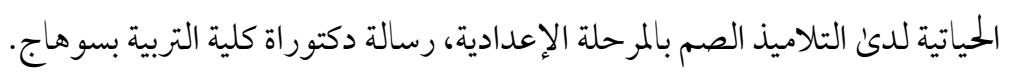

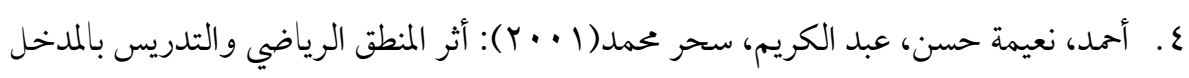

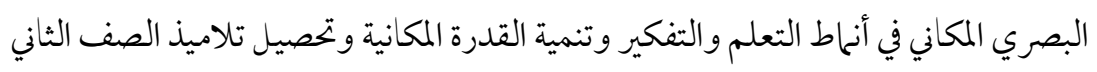

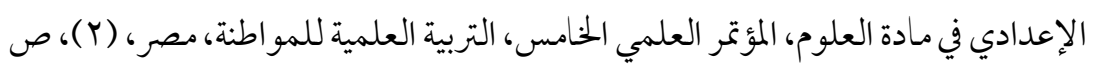
.OVV_OTO D

ه. باير، باري ك. (ع (199): الاستقصاء في الدراسات الاجتماعيةاستراتيجية للتدريس، ترجمة سليان محمد الجبر، الرياض، مكتبة العبيكان.

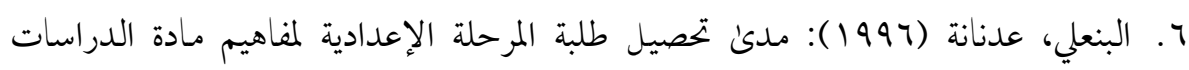

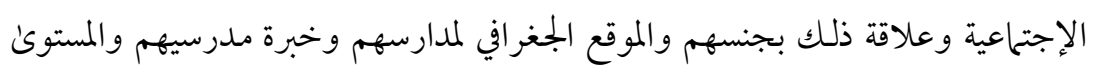

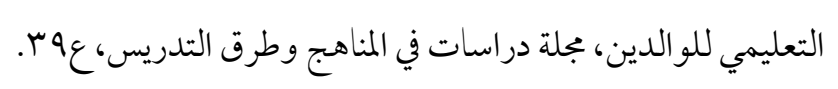

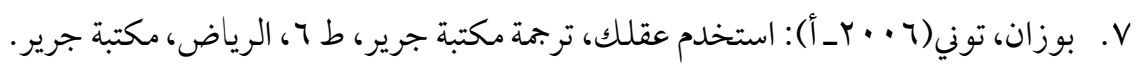



جرير. - (2)






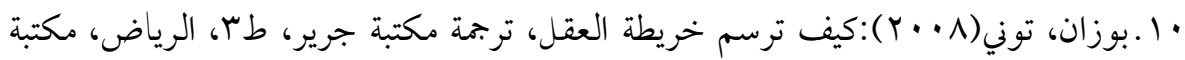

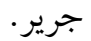
1 ا ـ بوزان، توني(9 + r):استخدم ذاكرتك، ترجمة مكتبة جرير، الرياض، مكتبة جرير. r ا ـبوزان، توني، بوزان، باري(• ( • (Y): خريطة العقل، ترجمة مكتبة جرير، طج، الرياض، مكتبة

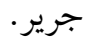

با ـ تلة، أزهار عبد المنعم محمد(ب( • Y): اعمال نصفي المخ باستخدام الخرائط الذهنية في تنمية مهار ات التفكير التاريخي والاتجاه نحو المادة لتلاميذ المرحلة الاعدادية، مجلة القراءة والمعرفة،

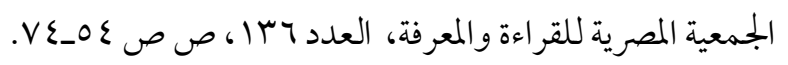

ع ا ـالجابري، أميرة عبد الحميد(V) . r): العلاقة بين كثافة العناصر في الرسومات التوضيحية وخلفياتها ونمو الإدراك البصري للمفاهيم البيئة لدى أطفال مـا قبل المدرسة، رسالة

$$
\text { ماجستير غير منشورة، كلية التربية، جامعة حلوان. }
$$

10.جودت، عبد السلام، هلال، ميس عريبي(0 + ب): فاعلية استراتيجيتي الخريطة الذهنية والتساؤل الذاتي في تحصيل طالبات الصف الخامس الأدبي في مادة تاريخ أوربا وأمريكا

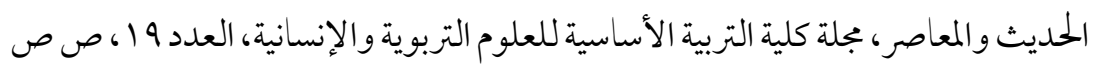

$$
. v 19-v \cdot r
$$

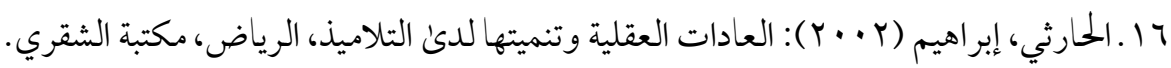


التحصيل وعادات العقل لدئ تلاميذ الصف الأول الإعدادي في مادة العلوم، الجمعية المصرية للتربية العلمية، المؤتمر العلمي الثاني عشر، التربية العلمية والو اقع المجتمعي، التأثير

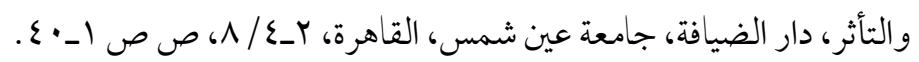

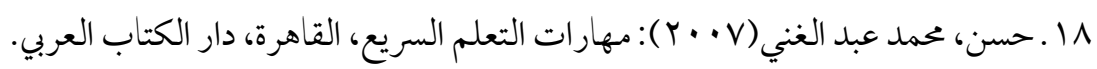


9 ا. حسين، أمينة راغب (11 + (Y): استخدام استراتيجية الخريطة الذهنية كمدخل لتنمية بعض مهارات التفكير لدئ الأطفال (برنامج مقترح)، رسالة ماجستير غير منشورة، كلية البنات، جامعة عين شمس.

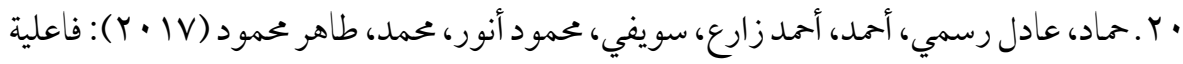
برنامج قائم علن الرسوم المتحركة في تدريس التاريخ لتنمية مهارات التفكير البصري لدئ

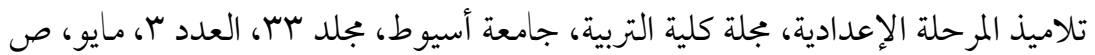

$$
.19 \cdot-174
$$

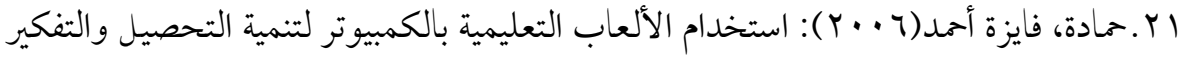
البصري في الرياضيات لدىن تلاميذ المرحلة الابتدائية، المجلة التربوية، كلية التربية بقنا،

$$
\text { جامعة جنوب الو ادي، العدد بr، يناير. }
$$

Y Y .حمادة، محمد محمود (9 + r): فاعلية شبكات التفكير البصري في تنمية مهارات التفكير البصري و القدرة على حل وطرح المشكلات اللفظية في الرياضيات والاتجاه نحو حلها لتلاميذ الصف الخامس الاتدائي، الجمعية المصرية للمناهج وطرق التدريس، دراسات في المناهج وطرق

$$
\text { التدريس، العدد 7 ع ا،مايو. }
$$

بr. حميدة، إمام غختار حميدة ( •99 199 ): استخدام الخرائط الزمنية في تنمية مفهوم الزمن لدىن تلاميذ الصف الأول الإعدادي، مجلة دراسات في المناهج وطرق التدريس، الجمعية المصرية

$$
\text { للمناهج وطرق التدريس، كلية التربية، جامعة عين شمس،ع ع. } 1 .
$$

ع ז.حميدة، فاطمة إبراهيم(1997 (1): المواد الاجتماعية أهدافها ومحتواها واستراتيجيات تدريسها،

$$
\text { القاهرة، مكتبة النهضة المصرية. }
$$

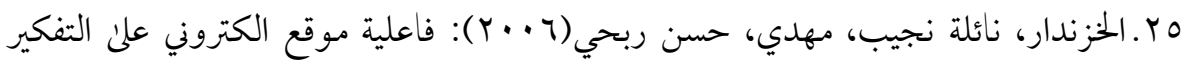
البصري والمنظومي في الوسائط المتعددة لدئ طالبات كليةو التربية بجامعة الأقصنى، الجمعية المصرية للمناهج وطرق التدريس، المؤتمر العلمي الثامن عشر مناهج التعليم وبناء الإنسان 



$.7 \leqslant 0$

جr بلف، يجي عطية (1991) ): تأثير مقرر التاريخ بالمدرسة الثانوية العامة والمدرسة المطورة على تحصيل الطلاب للمفاهيم التاريخية في المملكة العربية السعودية، مجلدات المؤتمر العلمي الثالث للجمعية المصرية للمناهج وطرق التدريس، الاسكندرية، مجلد ب. V V r. خليل، ابراهيم فاضل(• ( • ( ) المدخل إلى طرائق التدريس العامة، دار ابن الأثير، العراق، الموصل.

^ץ. الديب، عيد عبد الغني (1 (1 ·):فاعلية استخدام المنظمات البيانية لتنمية بعض عادات العقل اللازمة للتفكير البصري في الدراسات الاجتماعية لدى تلاميذ المرحلة الاعدادية، بجلة العلوم

$$
\text { التربوية، كلية التربية بقنا، العدد ب اله يناير. }
$$



$$
\text { في التعليم والتعلم، القاهرة، مكتبة الفلاح للنشر والتوزيع. }
$$

•r. الزيات، فتحي محمد (ץ · ·r): الأسس البيولوجية والنفسية للنشاط العقلي المعرفي، القاهرة،

$$
\text { دار النشر للجامعات. }
$$

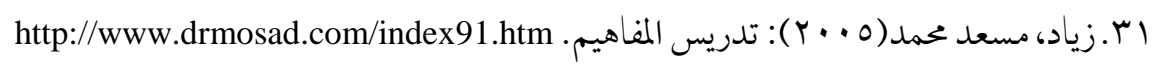

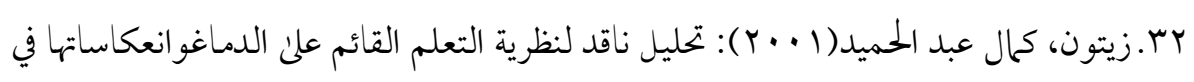
تدريس العلوم، الجمعية المصرية للتربية العلمية، المؤتمر العلمي الخامس، التربية العلمية

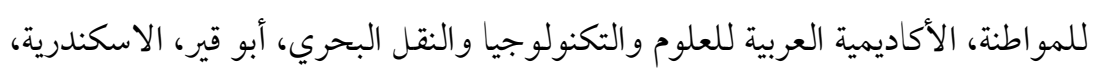

$$
. \wedge / 1: \vee / r q
$$

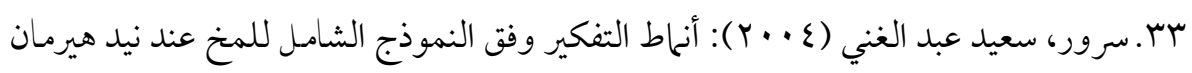
وعلاقتها بالذكاء المتعدد وأسلوب التعلم لدى' المعلمين قبل الخدمة، مجلة البحوث النفسية

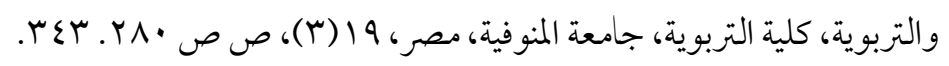




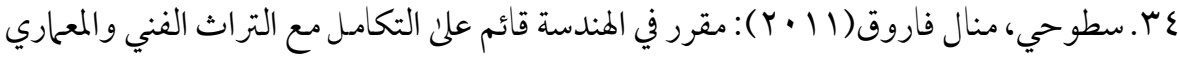
المصري لتنمية التفكير البصري الهندسي والوعي بهوية الرياضيات المصرية وقيم المواطنة لدنى طلاب المرحلة الاعدادية، الجمعية المصرية للمناهج وطرق التدريس، دراسات في المناهج

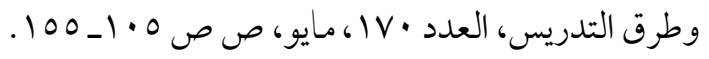
هr. سطوحي، منال فاروق(Y ( • (Y): استخدام نماذج اخبارية بوسائل الاعلام لأحداث جارية مع المنظات البيانية في تدريس الإحصاء لتنمية الحس الإحصائي وبعض عادات العقل والدافعية للإنجاز لدئ طلاب المرحلة الاعدادية، الجمعية المصرية للمناهج وطرق التدريس، دراسات

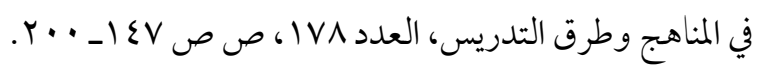


عادات العقل لدئ طلاب الصف الأول الثانوي من خلال مادة الكيمياء، الجمعية المصرية للتربية العلمية، المؤتمر العلمي العاشر، التربية العلمية، تحديات الحاضر ورؤئ المستقبل،

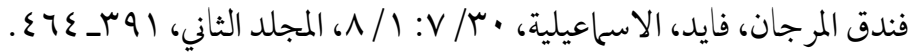
rV دراسات تربوية، مجلد ع، عددד اله القاهرة، عالم الكتب.


مهارات التعلم السريع لدىن عينة من طلاب الصف الثاني الثانوي بدولة الكويت، دراسة تجريبة ميدانية، الجمعية المصرية للمناهج وطرق التدريس، دراسات في المناهج وطرق

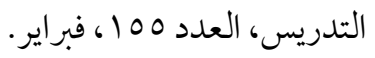

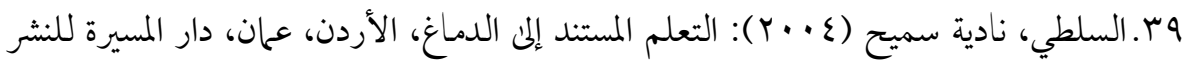
والتوزيع.

• ع . الشربيني، داليا فوزي عبد السلام(11 + (Y): أثر استخدام خرائط التفكير في زيادة التحصيل وتنمية مهارات اتخاذ القرار و التفكير البصري لدئ طلاب شعبتي الجغر افيا والتاريخ بكلية 
التربية، بجلة الجمعية التربوية للدراسات الاجتماعية، كلية التربية جامعة عين شمس،ع بس، ، هوب،

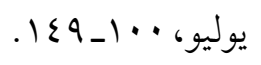

اع ـ شلبي، أحمد ابراهيم، خلف، يحي عطية سليمان، عبد العزيز، فهيمة سليان، الجمل، علي أحمد (1991): تدريس الدراسات الاجتماعية بين النظرية والتطبيق، القاهرة، المركز المصري للكتاب.

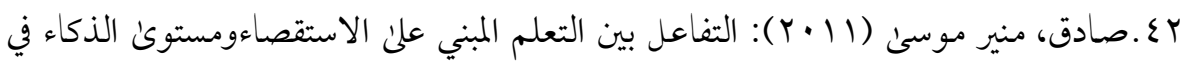
التحصيل وبعض عادات العقل والاتجاه نحو العلوم لتلاميذ الصف السابع الأساسي،

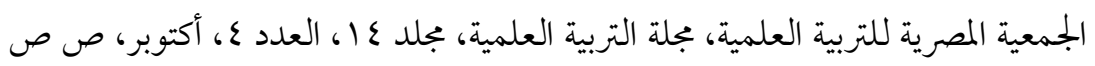

$$
\text { . } Y \xi Y_{-} 110
$$

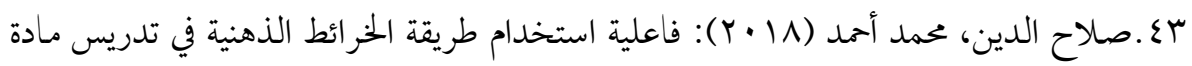
العلوم بالمرحلة الإعدادية، دراسة تطبيقية علن مدرسة خالد بن الوليد بدولة قطر، رسالة

$$
\text { ماجستير، كلية الدراسات العليا، جامعة أم درمان، السودان. }
$$

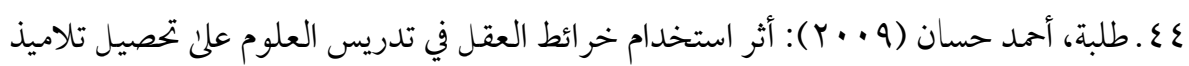

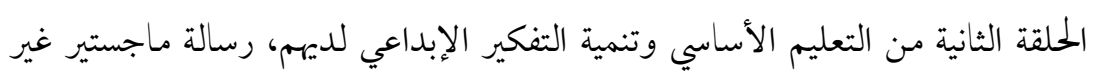

$$
\text { منشورة، كلية التربية، جامعة الفيوم. }
$$

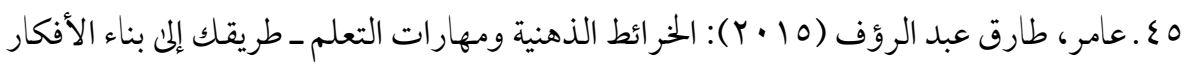

$$
\text { الذكية، القاهرة، المجموعة العربية للتدريب والنشر. }
$$

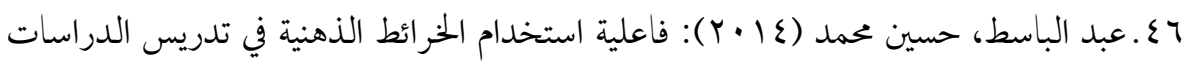
الاجتماعية علن تنمية أنماط التعلم و التفكير و التحصيل لدئ تلاميذ المرحلة المتوسطة بالمملكة

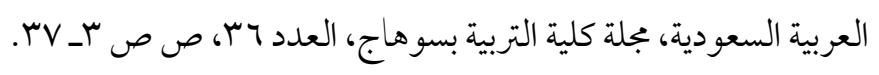


Vع ع عبد الحميد، ناصر السيد (11 (Y): استخدام استوديو التفكير في تدريس الرياضيات لتنمية عادات العقل التتج ومستويات التفكير التأملي لدئ تلاميذ الصف الأول الإعدادي، الجمعية المصرية للمناهج وطرق التدريس، العددس IV ، أغسطس.

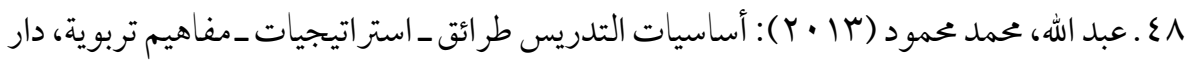
غيداء للنشر، عهان، الأردن.


لدئ تلاميذ الصف الأول الإعدادي في مادة العلوم، رسالة ماجستير غير منشورة، كلية البنات، جامعة عين شمس.

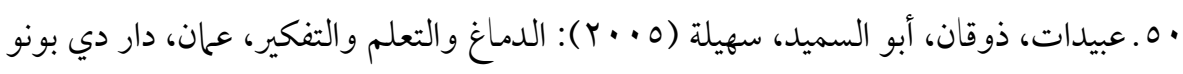
للنشر والتوزيع

ا 0 ـ العتيبي، منير (T + - Y): ثلاثة مو اضيع ثرية حول الخريطة الذهنية، بريد المعلم، السنة الخامسة، سبتمبر.

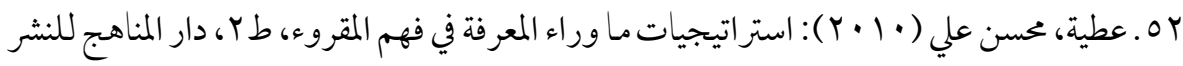
و التوزيع، عمان، الأردن.

ror. عطية، محسن محمد (990 1) : تذوق الفن الأساليب التقنيات المذاهب، القاهرة، دار المعارف.

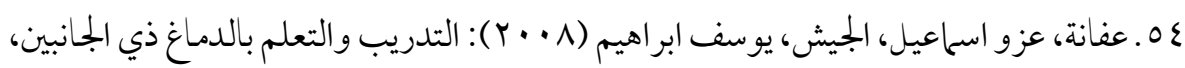
غزة، آفاق للنشر والتوزيع.

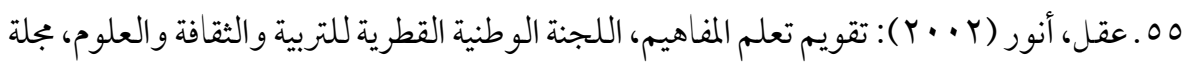

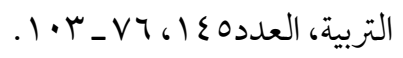
07 .عقل، محمود بدر (ع ·r): الأساسيات في تشريح الإنسان، عمان، دار الفكر للنشر والتوزيع.

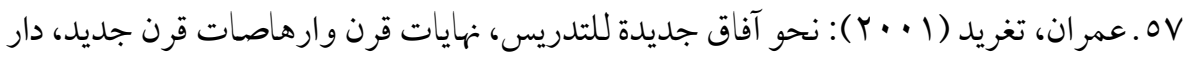
القاهرة للكتاب. 


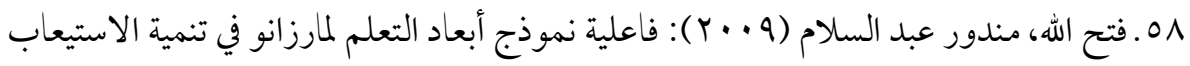
المفاهيمي في العلوم وعادات العقل لدئ تلاميذ الصف السادس الابتدائي، الجمعية المصرية

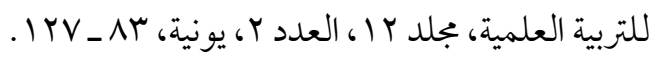

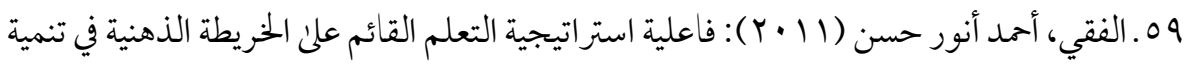
التحصيل ويعض المهارات التاريخية لدئ تلاميذ المرحلة الإعدادية، رسالة ماجستير غير

منشورة، كلية التربية، جامعة طنطا.

• . . فهمي، نوال عبد الفتاح (ع ( † ): خرائط العقل وأثرها في تنمية المفاهيم العلمية والتفكير البصري وبعض عادات العقل لدى تلاميذ الصف الرابع الابتدائي في مادة العلوم، مجلة

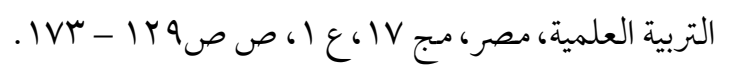

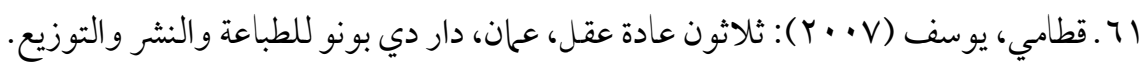

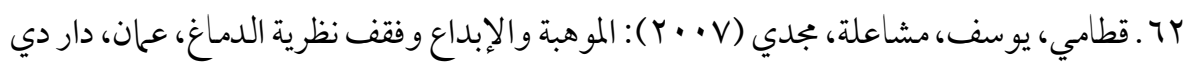

$$
\text { بونو للطباعة والنشر والتوزيع. }
$$

با ـ الكلثم، مها ابر اهيم، العناني، نسرين عبد الباسط، الدسوقي، منحئ محمد (9 ( ب): استراتيجيات

$$
\text { التدريس نحو تدريس فعال، السعودية: مكتبة المتنبي. }
$$

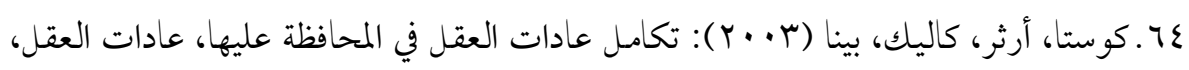



7. اللقاني، أحمد حسين، محمد، فارعة حسن، رضوان، برنس أحمد (• (199): تدريس المواد الاجتماعية، ط س، ج ا ، القاهرة، عالم الكتب.

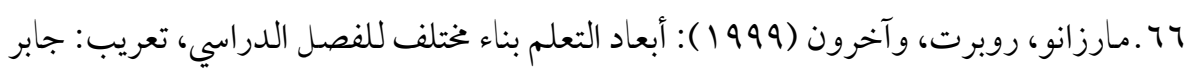

$$
\text { عبد الحميد وآخرون، القاهرة، دار قباء للطباعة والنشر والتوزيع. }
$$

Vا. مازن، حسام محمد (11 · Y): عادات العقل واستراتيجيات تفعيلها في تعليم وتعلم العلوم والتربية العلمية، لبجمعية المصرية للتربية العلمية، المؤتمر العلمي الخامس عشر، التربية 
العلمية، فكر جديد لواقع جديد، المركز الكشفي العربي الأول، القاهرة Y-V سبتمبر، ص

$$
\text { ص r }
$$

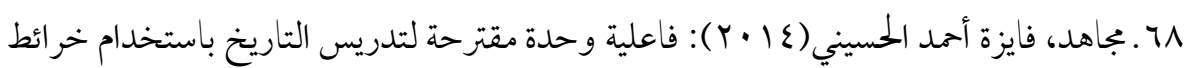

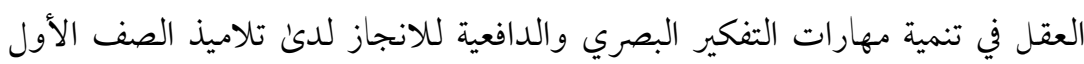

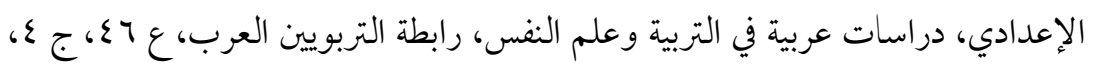

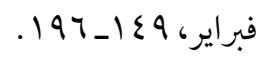

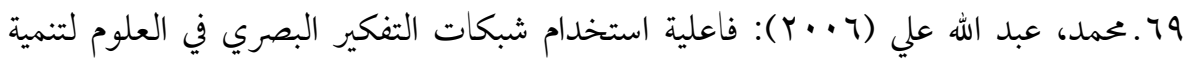

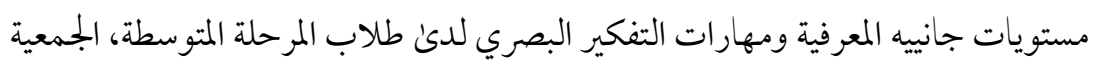

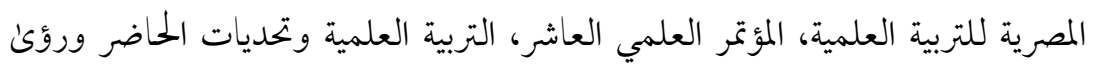

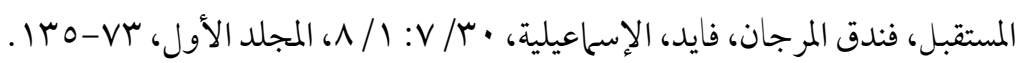



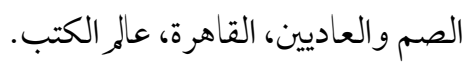

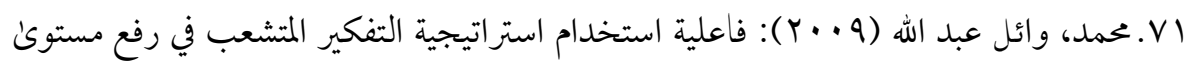
التحصيل في الرياضيات وتنمية بعض عادات العقل لدئ تلاميذ الصف الرابع الابتدائي

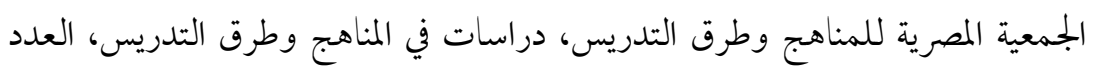
(10ب الم ديسمبر.

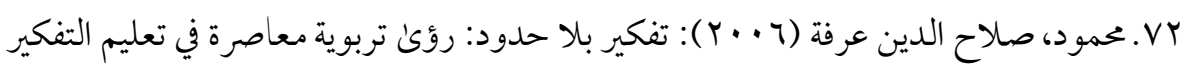

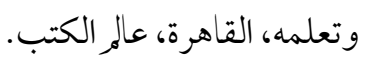

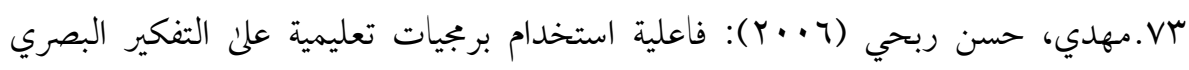

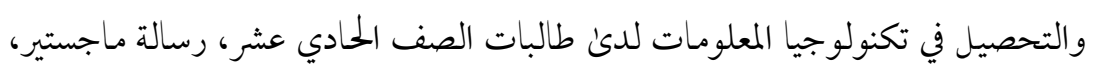

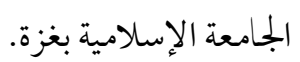




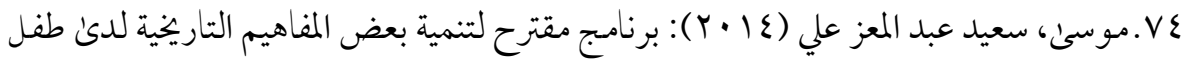



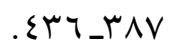

ه.المومني، رفاعي (910 (1)): العلاقة بين مدئ إكتساب معلمي الدراسات الاجتهاعية للصف الثالث الإعدادي في المدارس الحكومية في الأردن المفاهيم والتعميات والمهارات التاريخية ومدئ اكتساب طلبتهم في الصف نفسه لها، رسالة ماجستير، جامعة اليرموك، إربد، الأردن.

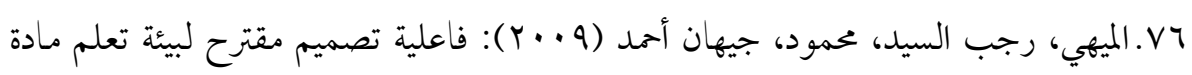
الكيمياء منسجم مع الدماغ في تنمية عادات العقل والتحصيل لدى طلاب المرحلة الثانوية ذوي أساليب معالجة المعلومات المختلفة، دراسات تربوية واجتماعية، كلية التربية، جامعة حلو ان، المجلد (10 )، العدد (1) )، يناير.

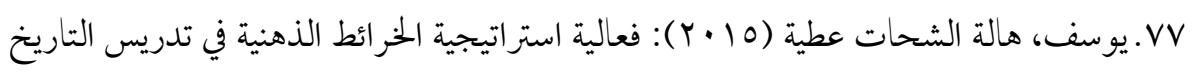
علن تنمية بعض مهارات التفكير المنظومي واتخاذ القرار لدىن طلاب الصف الأول الثانوي،

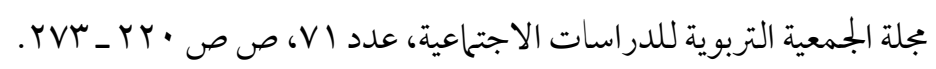




\section{Rferences}

- Ahmed, Naima Hassan, Abdul Karim, Sahar Mohammed (2001): the impact of mathematical logic and teaching visual-spatial entrance on patterns of learning and thinking and the development of spatial ability and the achievement of second-grade preparatory students in science, the fifth scientific conference, scientific education for citizenship, Egypt, (2) Pp. 525-577 (In Arabic).

- Ahmed, Osama Abdel-Rahman (2010): the effectiveness of a constructivistbased program using blended learning in teaching social studies on the development of geographic concepts, visual thinking and life skills of deaf students in the preparatory stage, Ph.D (In Arabic).

- $\quad$ Al-Binali, Adnanah (1996): The extent of the students of the preparatory stage of the concepts of social studies and its relationship with their gender and the geographical location of their schools and the experience of their teachers and the educational level of parents, Journal of Studies in Curricula and Teaching Methods, p 39 (In Arabic).

- Al-Harthy, Ibrahim (2002): Mental habits and development among pupils, Riyadh, Al-Shuqri Library. (In Arabic).

- $\quad$ Al-Jabri, Amira Abdel-Hamid (2007): The relationship between the density of elements in illustrations and their backgrounds and the growth of visual perception of environmental concepts in preschool children, unpublished master thesis, Faculty of Education, Helwan University. (In Arabic).

- $\quad$ Al-Khazindar, Nayla Najeeb, Mahdi, Hassan Ribhi (2006): The Effectiveness of a Website on Visual and Organizational Thinking in Multimedia among Students of the Faculty of Education at Al-Aqsa University, Egyptian Association for Curricula and Teaching Methods, Eighteenth Scientific Conference Hospitality, Ain Shams University, 25: 26/7, pp. 621-645. (In Arabic).

- $\quad$ Anderson, O.R. (1997): Aneuro Cognitive Perspective of Current Learning Theory and Science Instructional Strategies, Science Education, 81, 67-89. 
- $\quad$ Angelique, C. (2000): Problem Based Science Learning in a Mixed Ability Classroom that includes Gifted and Talented Children, M.S.U Tah-Stat University

- Aydin, A. B. (2009): Prepared Map and Concept Mind, Technolgically supported, the subjects of unit social and systems in our body by students, Procedia, Behavioral Sciences, 1(1) 2842.

- Baggett, P.V. (2009): Student Representation of Art Concepts through Mind Maps: University of South, Alabama, National Art Education Association, Ph.D., April 20.

- Bayer, Barry K. (1994): Investigation in Social StudiesStrategic Teaching, Translation by Sulaiman Mohammed Al-Jabr, Riyadh, Obeikan Library (In Arabic).

- $\quad$ Beyer, B. (2003): Improving Student Thinking, The Clearing House, 71(5) 262267.

- $\quad$ Brown, H. D.(1989): Prhnciples of language learning and teaching, New Jersey, Prentice-hall.

- Buzan, T.(1994): The Mind Map Book How to use Radiant Thinking to Maximize Your Brains Untapped Potential, Dutton Book, Penguin Group.

- Buzan, T.(2000): Visual Thinking: Executive Power Tool of the 21 th Century, Innovation Tools Artcle-Visual Thinking, Executive Power Tool 4,htm.

- Buzan, Tony (2006a): Use your mind, translation of Jarir Bookstore, i 6, Riyadh, Jarir Bookstore (In Arabic).

- Buzan, Tony (2006b): Using Mind Maps at Work, Translation of Jarir Bookstore, Riyadh, Jarir Bookstore (In Arabic).

- $\quad$ Buzan, Tony (2007): Maps of Mind, Jarir Bookstore Translation, Riyadh, Jarir Bookstore. (In Arabic).

- Buzan, Tony (2008): How to draw a mind map, translation of Jarir Bookstore, 3rd floor, Riyadh, Jarir Bookstore. (In Arabic).

- Buzan, Tony, Buzan, Barry (2010): Map of the Mind, translation of Jarir Bookstore, 6th Floor, Riyadh, Jarir Bookstore. (In Arabic). Busan, Tony http://dx.doi.org/10.29009/ijres.3.3.10 
(2009): Use your memory, translation of Jarir Bookstore, Riyadh, Jarir Bookstore. (In Arabic).

- Cambell, J. (2010): Theorizing Habits of Mind as a Framework for Learning, http://www.aare.edu.au106pap/cam06102.pdf.

- $\quad$ Chaill, M. \& Fonteyn, M. (1998): Using Mind Mapping to Improve Students Metacognition (Book) Clinical Reasoning in the Health Professions, Joy Higgs, Mark A. Jones 217-220.

- Coll, R. et al. (2009): Scientists' Habits of Mind as Evidenced By the Interaction between their Science Training and Religious Beliefs, International Journal of Science Education, 31(6), 725-755.

- Coombs, C. P. (2001): Reflective Practice Developing Habits of Mind, Ph.D. Toronto Canada.

- Costa, A. \& Kallick, B. (2000): Activating and Engaging Habits of Mind, Association for supervision and curriculum development, Alexandria, Virginia.

- Costa, A. (2001): Developing Minds: A Resource Book of Teaching Thinking, Third Edition, Alexandria, VA: Association for Supervision and Curriculum Development.

- $\quad$ Costa, A. and Kallick, B. (2009): Habits of Mind Across the curriculum Practical and Creative Strategies for Teachers, Association for Supervision and Curriculum Development, Alexandria, Virginia, U.S.A.

- $\quad$ Cunningham, G.E. (2005): Mind Mapping: its Effects on Student Achievement in high school Biology, Faculty of the Graduate School, University of Texas, Ph.D., Austin UMI Number: 3215351 Proquest.

- $\quad$ Elise, M. et al.(1997): Promoting Social and Emotional learning, Alexandria, VA: Association for supervision and curriculum Development.

- $\quad$ Evrekli, E. et al. (2009): Mind Mapping Applications in Special Teaching Methods Courses for Science Teacher Candidates and Teacher Candidates Opinions Concerning the Applications, A Faculty of Buca Education, Dokuz Eylul University, turkey, January, 2274-2279. www.sciencedirect.com. 
- Ganguly, I. (1995): Scientific thinking is in the Mind's Eye, Reports Evaluative, Speeches, Meeting Papers, ERIC ED391504.

- Goldenberg, E.P. (1996): Habits of Mind as an Organizer for the Curriculum, Journal of Education, 78(1).

- Hamada, Fayza Ahmed (2006): The use of educational computer games to develop the achievement and visual thinking in mathematics among primary school students, Educational Journal, Faculty of Education, Qena, South Valley University, No. 22, January. (In Arabic).

- Hamada, Mohamed Mahmoud (2009): Effectiveness of Visual Thinking Networks in Developing Visual Thinking Skills and Ability to Solve and Solve Verbal Problems in Mathematics and Towards Solving them for Fifth Grade Students, Egyptian Association for Curriculum and Instruction, Studies in Curriculum and Instruction, No. 146, May. (In Arabic).

- Hamida, Fatima Ibrahim (1996): Social Objectives, Content and Teaching Strategies, Cairo, Egyptian Renaissance Library. (In Arabic).

- Hamida, Imam Mokhtar Hamida (1990): Using Time Charts in Developing the Concept of Time for First Preparatory Students, Journal of Studies in Curricula and Teaching Methods, Egyptian Association for Curriculum and Instruction, Faculty of Education, Ain Shams University, p. 8. (In Arabic).

- Hammad, Adel Rasmi, Ahmed, Ahmed Zarey, Swify, Mahmoud Anwar, Mohamed, Taher Mahmoud (2017): The Effectiveness of Animation-Based Program in Teaching History to Develop Visual Thinking Skills for Preparatory Students, Journal of the Faculty of Education, Assiut University, Vol. 33, No. 3, May, pp. 162--190. (In Arabic).

- $\quad$ Harkirat, S. et al. (2010): Constructivist-Visual Mind Map Teaching Approach and the Quality of Student's Cognitive Structures. Journal of Science Education and Technology, 20(2), 186-200.

- Hassan, Mohamed Abdel Ghani (2007): Accelerated Learning Skills, Cairo, Dar Al Ketab Al Arabi. (In Arabic). 
- $\quad$ Hossam El-Din, Laila Abdullah (2008): The Effectiveness of the Strategy of "Beginning, Response, Evaluation" in Developing the Achievement and Habits of Mind among First Grade Students in Science, Egyptian Society for Scientific Education, 12th Scientific Conference, Scientific Education and Social Reality, Influence And Impact, Guest House, Ain Shams University, Cairo, 2-4 / 8, pp. 1 - 40. (In Arabic).

- Hyerle, D. (1999): Visual Tools and Technologies, New York, Designs for Thinking.

- Ibrahim, Khairy (1996): Social subjects in the educational curricula between theory and practice, Alexandria, University of Knowledge (In Arabic).

- Ibrahim, Magdy Aziz (2002): Effective Teaching and Management Skills, Cairo, Anglo-Egyptian Library (In Arabic).

- Ismail, N. et al. (2010): The effects of Mind Mapping with Cooperative learning on programming performance Problem solving Skill and meta computer Science student's Journal of Educational Computing Research, 42(1) 35-61.

- Jawdat, Abdul Salam, Hilal, Mays Oraibi (2015): The Effectiveness of Mental Map Strategies and Self-Questioning in the Achievement of Fifth Grade Literary Students in the History of Modern and Contemporary Europe and America, Journal of the College of Basic Education for Educational and Human Sciences, No. 19, pp. 703-719. (In Arabic).

- Jensen, E. (2000): Brain-Based Learning, Academic Press Inc., Alexandria Virginia.

- Jones, B. et al. (2012): The effects of Mind Mapping Activities on Student's Motivation' International Journal for the Scholarship of Teaching and Learning, 6(1) 1-21.

- $\quad$ Khalaf, Yahia Attia (1991): The Effect of History Course in General Secondary School and Developed School on Students' Achievement of Historical Concepts in Saudi Arabia, Volumes of the Third Scientific Conference of the Egyptian Association for Curricula and Teaching Methods, Alexandria, Vol. 3. (In Arabic). 
- $\quad$ Khalil, Ibrahim Fadel (2010): Introduction to General Teaching Methods, Dar Ibn Al Atheer, Iraq, Mosul. (In Arabic).

- $\quad$ Klausemier, H.J. \& Sipple, T. (1980): Learning and Teaching Concepts, New York Academic Press, in Robert Marzano et al. ASCD, Virginia.

- $\quad$ Leonidas et al. (2007): Creativity Development in Engineering Education: The Case of Mind Mapping, Journal of Management Development, 26(4); 370380 .

- $\quad$ Ling, L.L. (2006): Using a Computer-Based Multimedia Culture Mind Map as an Instructional Module for EFL Reading Comprehension and Vocabulary: the effect on Student Achievement-Among College Freshmen in Taiwa, Idaho State University, Proquest, AAT 3231710.

- Maeckelbergh, A.F. (2006): The Creation of an Organization Development Visual Reference Tool, doctoral of Education Unviersity of St. Thomas, Saint Paul, Minnesota, December, Proquest, UMI Number (3240303).

- Marzano, R.J. (2000): Transforming Classroom Grading, Alexandria, VA: ASC.

- $\quad$ McCormack, A. (1993): VISTA: Visual Spatial Thinking Activities, San Diego State University fdm. March.

- National Curriculum (2005): Developments in Science in Teaching, London, Open Books.

- National Education Association (NEA) (2007): Understanding the Indoor Environment Movement of Air, Maind Map Activity, Lesson 7 Movement of Air Maind Map Activity, http://www.epa.Gov/iaq/schools/actionkit.html.

- $\quad$ Nemirovsky, R. And Tracy, N. (1997): On Mathematical Visualization and the place where we live, Educational studiesin mathematics, 33(2) July, pp. 99131.

- $\quad$ Oldfather, P. et a 1.(1994):Drawing the Circle Collaborative Mind Mapping as a Process for developing a constructivist teacher perception program, Teacher Education Quality, 21(3) pp 15-26.

- Plough, J.M. (2004): Students using Visual Thinking to Learn Science in a WebBased Environment, Ph. D., Drexel University. 
- $\quad$ Poision, (2004):

- $\quad$ Rayan, Mohammed Hashem (2006): Teaching Strategies for Developing Thinking and Training Facts, Teacher's Guide to Teaching and Learning, Cairo, Al-Falah Library for Publishing and Distribution. (In Arabic).

- Rotta, A. (2004): All Students Can learn All students Can Succeed, Alexandria, VA: ASC.

- $\quad$ Rusevic, A.R. (1997): Development of a performance based assessment of visual thinking for talented middle grade student D.A.I. 57(7), January, 2869A.

- Talah, Azhar Abdel Moneim Mohamed (2013): the work of the hemispheres of the brain using mental maps in the development of historical thinking skills and the tendency towards the material for the pupils of the preparatory stage, Journal of Reading and Knowledge, the Egyptian Association for Reading and Knowledge, No. 136, pp. 54-74. (In Arabic).

- $\quad$ Talbot, W.D. et al. (1997): A Course of Study for Art is Elementary (Teaching Visual Thinking through Art Concepts) K-6 Guides-Classroom-Teacher, ERIC, Ed210236.

- Trevino, C. (2005): Mind Mapping and Outlining: Comparing two Types of Graphic Organizers for Learning Seventh-Grade Life Science Ph.D., Faculty of Texas Tech University, May.

- Victor, R. \& Valqui, V. (2006): Informatics and Mathematical Modeling, European Journal of Operational Research, Vol (174) Oct. 1348-1349.

- Wolfe, P. \& Brandt, R. (1999): What do we Know from Brain Research?, Educational Leadership, 56(3), 8-13.

- Wycoff, J. (2000): Mind Mapping Techniques and Practical Applications, Visual Thinking Executive Power Tool 4. htm.

- Zaytoun, Kamal Abdel Hamid (2001): A Critical Analysis of the Theory of Brain-Based Learning and its Implications in Science Teaching, Egyptian Association for Scientific Education, Fifth Scientific Conference, Scientific Education for Citizenship, Arab Academy for Science and Technology (In Arabic). 
- Ziad, Mosaad Mohamed (2005): Teaching concepts. http://www.drmosad.com/index91.htm (In Arabic).

- Zumback, J. (2008): The Role of Graphical and Text Based Argumentation tools in hypermedia tool, Article in Press, Comptuer in Human Behaviour, Unviersity of Salzburg, Austria, Aug 6.

- $\quad$ Zyryanova, N. M. (1998): Twin Study of IQ and Visual Thinking in Children Psychological Institute of RAE, Moscow, Russia, 1. Http://allserv. rug.ac.be/ ivanmerv/ecp8095.html. 